\author{
William E. MacHardy \\ University of New Hampshire, Durham \\ David M. Gadoury \\ Cornell University, New York State Agricultural Experiment Station, Geneva \\ Cesare Gessler \\ Swiss Federal Institute of Technology, Zürich, Switzerland
}

\title{
Parasitic and Biological Fitness of Venturia inaequalis: Relationship to Disease Management Strategies
}

Nelson (59) defines biological fitness as an organism's relative ability to persist over time. Any trait that contributes to increased reproductive capacity and/or survival is a biological fitness character. Parasitic fitness is the relative ability of a parasitic genotype or population to persist successfully over time. Both types of fitness are measured in terms of reproductive success. In Nelson's view (59), "The long process of coevolution resulted in the ultimate accumulation of many resistance and fitness genes in the host and parasite, and the result is that subsequent changes in the future course of their continuing coevolution will be largely subtle ones."

In other words, over time the relationship between a parasite and its host becomes "fine-tuned," and the relationship between Venturia inaequalis (Cooke) G. Wint., the fungal parasite that causes apple scab, and its host, Malus $\times$ domestica, appears to be finely tuned indeed. $V$. inaequalis is a successful parasite on apple because it has accumulated numerous parasitic fitness attributes (genes) that enable it to infect and reproduce, but with little apparent cost (damage) to the host. When a spore produced by $V$. inaequalis lands on a susceptible apple leaf and conditions are favorable for infection, invasion is restricted to the space between the cuticle

Dr. MacHardy's address is: Department of Plant Biology, Spaulding Hall, University of New Hampshire, Durham 03846; E-mail: machardy@ christa.unh.edu.

Dr. Gadoury's address is: Department of Plant Pathology, Cornell University, New York State Agricultural Experiment Station, Geneva, NY 14456; E-mail: dmg4@nysaes.cornell.edu.

Dr. Gessler's address is: ETH Zürich Institut für Pflanzenwissenschaften, ETH Zentrum/LFW, Universitätstrasse 2, CH-8092, Switzerland; Email: cesare.gessler@ipw.agrl.ethz.ch.

Publication no. D-2001-0809-01F

(C) 2001 The American Phytopathological Society and the epidermis (Fig. 1), and there is almost no noticeable damage to host tissue 1 to 3 weeks later when a scab lesion appears. Apple survives because it has accumulated numerous biological fitness attributes (genes) that enable it to cope with the parasite: scab is not life threatening, and a tree can withstand numerous infections and bear fruit (produce seed).

In this article, we discuss the fitness attributes that make $V$. inaequalis a successful parasite on apple and enable apple to cope with it. $V$. inaequalis is not an obli-

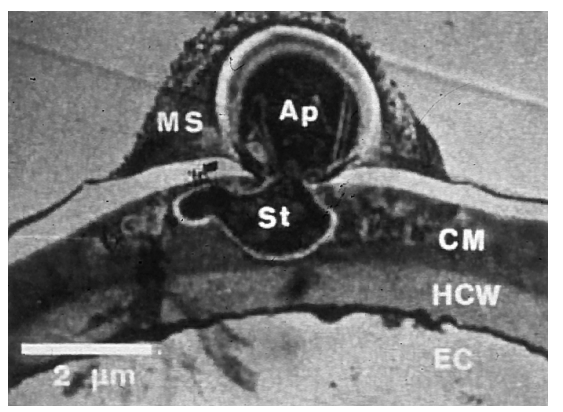

Fig. 1. Small, undifferentiated stroma of Venturia inaequalis between the host cell wall and cuticular membrane. Ap, appressorium; CM, cuticular membrane; EC, epidermal cell; HCW, host cell wall; MS, mucilaginous substance; St, stroma (83). Reprinted by permission.

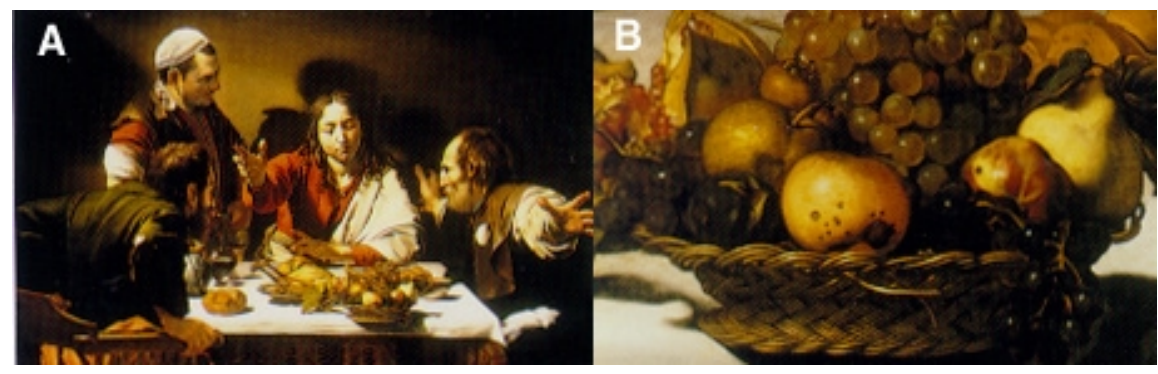

Fig. 2. "The Supper at Emmaus" by Michelangelo M. da Caravaggio, painted c. 1600. Enlargement of the basket of fruit shows clearly several scab lesions on the apples. Published by kind permission of the Trustees of the National Gallery, London. 


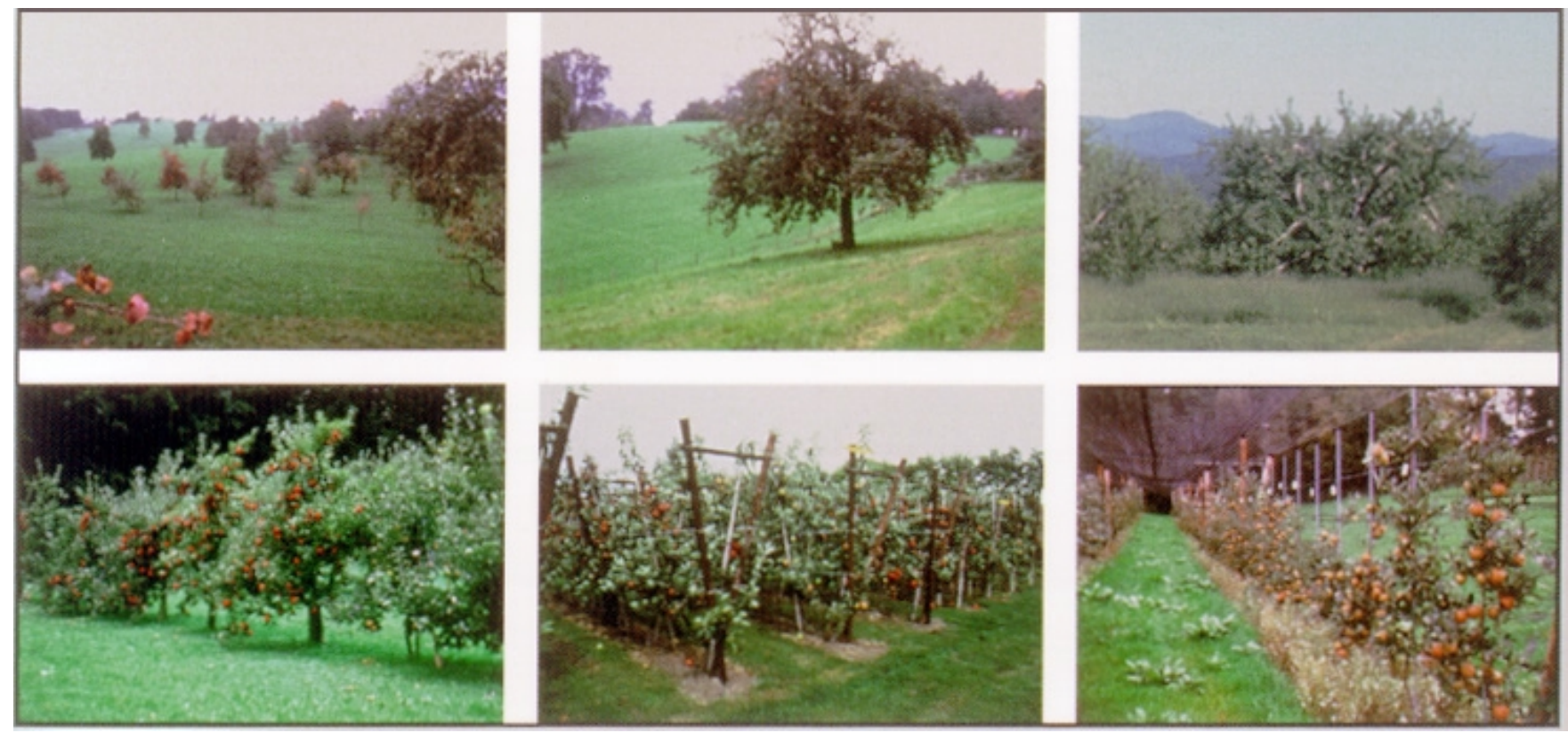

Fig. 3. The progression of orchards from a meadow orchard (upper left) of mostly crabapple seedlings grafted with sweet varieties and interspersed with pear and other fruit trees, no row structure, and trees often widely spaced (upper middle) to modern orchards with genetically uniform trees planted in rows, first of large standard trees (upper right), then of trees grafted onto semidwarfing (lower right and middle), and finally onto dwarfing (lower right) rootstock that resulted in much smaller trees and much greater planting densities.

Why was scab apparently not a serious problem to growers until the 1800 s? One suggestion is that scab was present for centuries but remained obscure because apple trees with high resistance to scab were grown as seedlings in small plantings. In Europe during medieval times, apple plantings were in monasteries and other religious havens, and the diversity of resistance genotypes in the seedlings was most likely responsible for maintaining infection at a low frequency. In more recent times, particularly in Europe until the early 1900s, apple was also grown on farms (mainly for family use) in meadow orchards planted with trees (mostly crabapple seedlings grafted with sweet varieties) widely spaced and interspersed with pear and other fruit trees (Fig. 3). Single apple trees at the borders of fields and apple trees along roads were also common. A high number of different varieties was probably present, so we can assume that each tree was mostly surrounded by trees of a different genotype (23). The distance for ascospores (the primary inoculum) to travel from the ground to different trees, the diversity of genotypes in seedlings, and practices such as cultivation and grazing by sheep and cows that very likely removed infected leaf litter, all mitigated the severity of scab and kept the disease from rendering the fruit unusable. All that changed in the 1800 s when controlled pollination followed by vegetative propagation resulted in the production of genetically uniform trees with improved characteristics (47) and increased consumer demand for fresh apples and for specific apples required changes in marketing and in apple production. In response, farmers started to produce apples for sale at markets (before, only cider was sold, as fresh apples were for the farmer's own use): desirable cultivars were planted in the meadow orchards, and in a significant departure from custom, the trees were planted in rows (Fig. 3). These orchards were the forerunners of today's orchards and marked the beginning of modern apple production. The new practices were less effective in reducing leaf litter, and the dispersal distance for ascospores was shortened considerably. The stage was set for scab to become a major problem, and scab epidemics requiring control to save the fledgling apple industry occurred in the 1880s (60).

In the United States, apple production did not flourish until the 1800 s. Before that time, orchards were comprised mostly of seedling trees, with about $10 \%$ of the trees bearing grafted scions, but by the mid1800 s, orchards of grafted clonal trees were common (8). Such orchards increased rapidly in the mid-1800s. Losses due to insects and diseases, particularly codling moth, Cydia pomonella (Linnaeus), and scab also increased, but the causes were poorly understood and there were few effective control practices. Consequently, by the latter part of the 1800 s, orchards were being cut down (8).

Scab is unacceptable only in commercial production because the market has imposed a high standard of quality for the fruit. As Nelson (59) noted, "While natural populations of hosts learned to live with their parasites, man could not or would not." This appears to be true of apple and $V$. inaequalis, because they had apparently

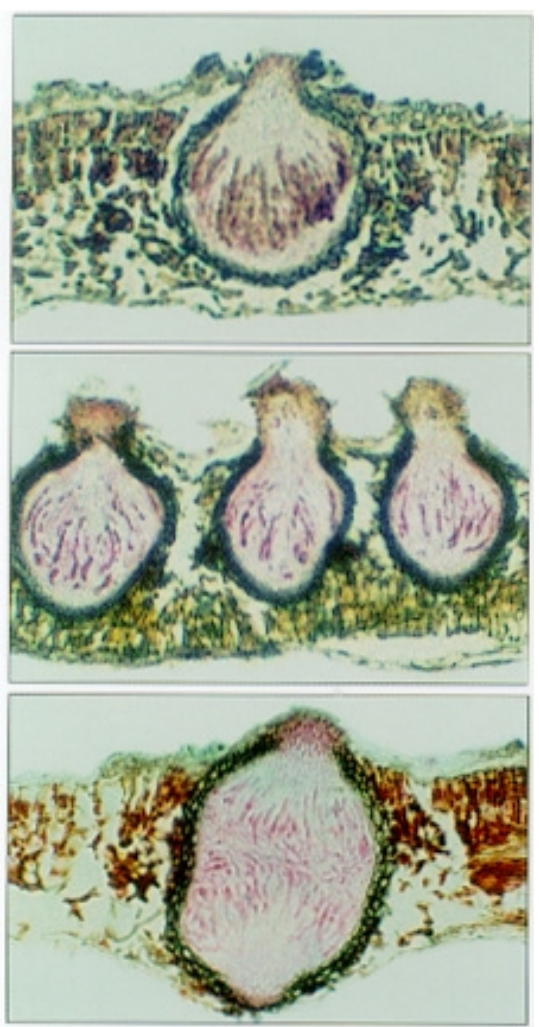

Fig. 4. Negative geotropism in ascocarp formation. Top, Leaf overwintered with adaxial surface uppermost showing pseudothecium with adaxially directed ostiole; center, leaf overwintered with abaxial surface uppermost showing pseudothecia with abaxially directed ostioles; and bottom, leaf repeatedly flipped during overwintering showing biostiolate pseudothecium (27). 
learned to live with one another quite well before mankind began to tinker with the natural ecosystem. In the final section, we discuss the evolution of practices and programs to control, and later manage, scab, and we conclude with speculation on future directions of management.

\section{Saprophytism}

Ascospores produced within pseudothecia (Fig. 4) in fallen infected leaves constitute the principal, and often sole, source of primary inoculum for apple scab. Pseudothecia mature only after a protracted period of development, and ascospores do not mature until spring. What, then, are some of the salient features of the ascigerous state, and what is it about these features that might conceivably make $V$. inaequalis a better pathogen of apple?

The ascigerous state is not initiated until the infected host leaves die. Within a few days after leaf abscission, hyphae from the subcuticular stroma grow downward into the palisade and mesophyll tissues of the leaf and there form the stromatic spheres that develop, after fertilization by a compatible mating type, into immature pseudothecia.

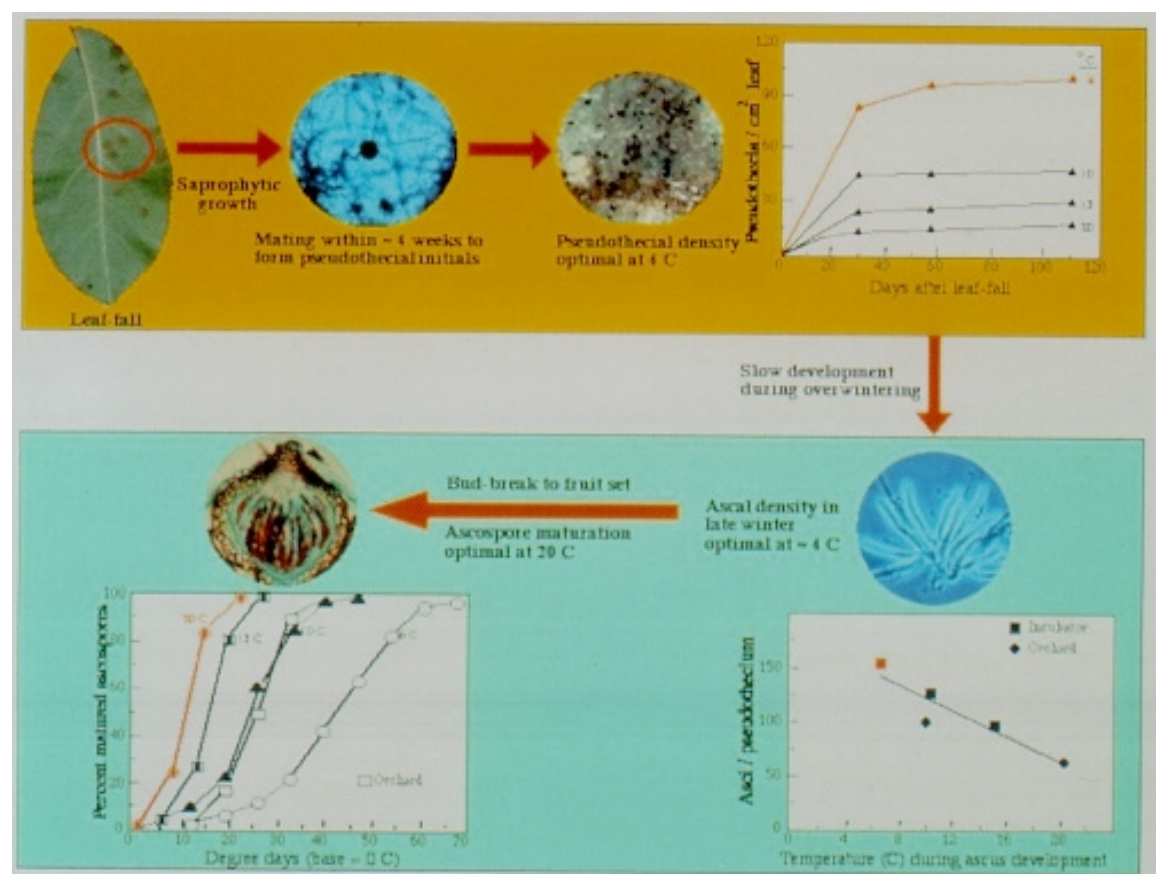

Fig. 5. Adaptation of Venturia inaequalis development during its sexual stage while the host is dormant to host phenology in spring as evidenced by thermal optima for pseudothecia initiation, ascal density, and ascospore maturation.
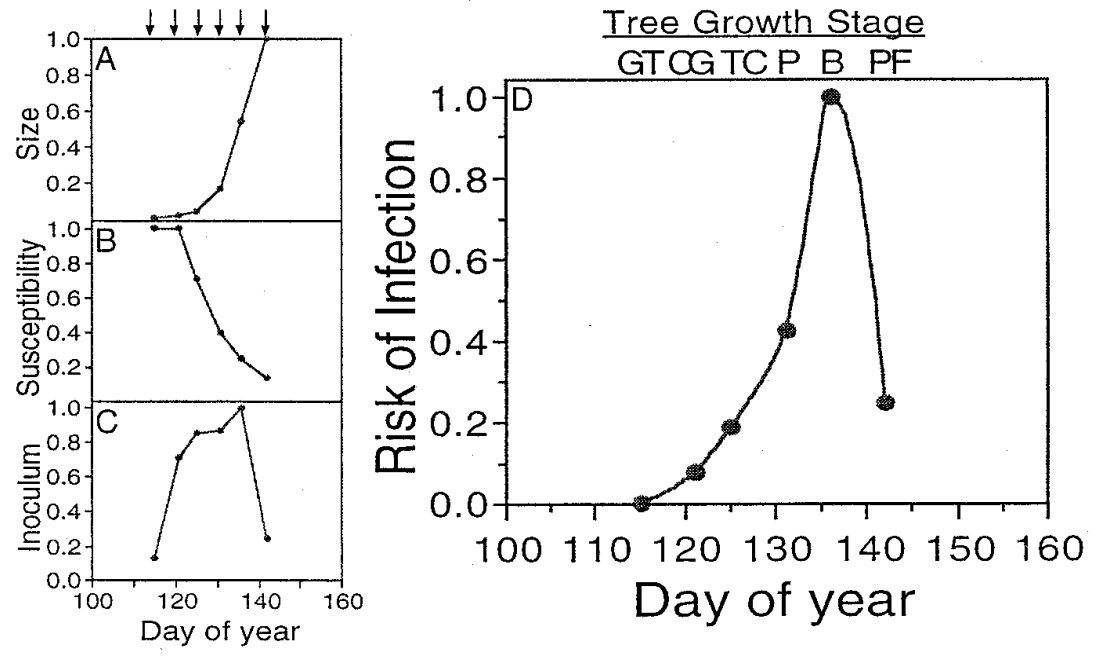

Fig. 6. Changes in leaf cluster size (A); susceptibility to scab (B); and amount of airborne inoculum of Venturia inaequalis (C) with growth stage of McIntosh trees. The product of $A^{*} B^{*} C$ is the relative risk of infection (D). GT = green tip, $C G=12.5 \mathrm{~cm}$ green, $T C=$ tight cluster, $P=$ pink, $B=$ bloom, and $P F=$ petal fall (19).

The pseudothecium is negatively geotropic during its development (27). Irrespective of which leaf surface was infected during the parasitic phase, the ostiole will be directed toward the surface of the fallen leaf that faces away from the earth and thus toward the orchard air (Fig. 4A and B). This orientation can be observed in early spring, can even redirect growth in disturbed leaf litter (Fig. 4C), and increases the probability that ascospores will eventually be carried aloft.

Pathogen populations are comprised of two mutually exclusive mating types. Thus, there is a strong correlation between disease severity and the probability that two compatible mating types will be present within the same leaf (28). More intense disease results in a higher percentage of leaves bearing fertile pseudothecia. However, the pathogen may have a backup system that ensures that some ascocarps will form, even at the lowest levels of disease incidence. We found that even at trace levels of disease in autumn, approximately $3 \%$ of the leaves bearing single lesions produced pseudothecia (28). Exactly how this is accomplished is unclear. However, it might be accomplished by dispersal of diads, triads, or tetrads of ascospores from the same ascus. If these were dispersed and then infect together, then both mating types might be harbored within a single lesion. Another, perhaps more plausible explanation, is that bipolar heterothallic systems are not quite as cut and dried as we might like to believe, and that some isolates of $V$. inaequalis retain the capacity of selfing. This has been demonstrated in Uncinula necator, where certain isolates will cross in protracted associations with a second isolate that appears initially to be incompatible (31). Coincidentally, the frequency of these oddball isolates was approximately $3 \%$ in a population of U. necator.

Adaptation toward tree phenology (Fig. 5). Apple is a deciduous, temperate zone fruit, and there are features of the development of the ascigerous state of $V$. inaequalis that are particularly well suited to survival of apple's dormant period. The thermal optima for the phases of ascocarp initiation and development vary through time as seasonal temperatures decline after leaf fall and then rise again in spring. Pseudothecia are initiated soon after leaf abscission, most within 1 month of leaf fall (24). They increase in diameter most rapidly at temperatures near $10^{\circ} \mathrm{C}$, but their numbers per unit of infected leaf are maximized at temperatures near $4^{\circ} \mathrm{C}$ (24). No detectable growth or differentiation occurs at or below $0^{\circ} \mathrm{C}$. Most pseudothecia enter winter as spheres of stromatic tissue approximately $40 \mu \mathrm{m}$ in diameter.

Pseudothecial development accelerates as late-winter temperatures increase, and the change in thermal optima for development reflects the rise in mean daily temperatures. The number of asci per ascocarp 
is inversely proportional to temperature during ascus proliferation (late-winter) and is maximized near $4^{\circ} \mathrm{C}(29)$. As temperatures continue to increase, ascospores are formed by free-cell formation. Their rate of maturation is maximized near $20^{\circ} \mathrm{C}(24)$.

This relationship between temperature and productivity, differentiation, and maturation has several advantages for $V$. inaequalis. First, the low thermal optimum of the pathogen at leaf fall maximizes the numbers of pseudothecia formed at the cooler temperatures that prevail at this time. The very slow development at temperatures near $0^{\circ} \mathrm{C}(84)$ and the subsequent increase in the thermal optimum for maturation have the net effect of synchronizing the initial maturation of ascospores with the initial emergence of host tissue from flower buds of the host. The degree of synchrony is nothing short of remarkable when you consider that the overwintering structure of the pathogen is often initiated a full 5 months before bud break. Furthermore, the dates of leaf fall and bud break can vary substantially at a single site, and the duration of the period between leaf fall and bud break may be as short as 3 months or as long as 6 months. Despite this variation, the pathogen consistently produces the first mature ascospores within a few days of bud break of the host (33).

There is evidence of further adaptation toward host phenology. $V$. inaequalis consistently discharges the bulk of its ascospores at the precise host phenological stage when they are most likely to successfully infect the host (Fig. 6). The fruit buds of apple trees pass through a succession of growth stages (phenophases) during the first 8 weeks of the growing season as leaves emerge as a rosette subtending the flower cluster. Fruit buds predominate on mature trees, and their development precedes that of vegetative buds by approximately 2 weeks. Host tissue is a target for airborne ascospores of $V$. inaequalis, and the probability of a spore contacting host tissue is a function of the target size and density.

During rain, ascospores are forcibly discharged to heights of 0.1 to $13.2 \mathrm{~mm}$ above the surface of overwintered leaves on the orchard floor (5). Thereafter, ascospores are carried aloft by turbulence and move through tree canopies on roughly horizontal trajectories until they either settle to the ground, contact the tree, or leave the orchard (33). Host tissue can therefore be represented as a two-dimensional target, i.e., the cross-sectional or silhouette area of the susceptible leaf and floral tissue emerging from apple buds (19). For the purpose of describing temporal changes in target size, one can consider a single fruit bud or the mean development of a group of fruit buds. Initial target size is 0 in dormant buds. Target size increases slowly through green tip and $1 \mathrm{~cm}$ green and then increases exponentially between $1 \mathrm{~cm}$ green and late pink, reaching a maximum size at petal fall (Fig. 6A).

If target size were the only factor involved, then to maximize the probability of successful establishment, ascospore discharge would be delayed until leaves are fully expanded. And yet the peak of ascospore discharge occurs earlier with respect to host phenology. An additional factor to consider is that the susceptibility of leaves that emerge from fruit buds decreases with age (Fig. 6B), i.e., the leaves acquire ontogenic resistance (19). The probability of successful establishment is therefore maximized when the product of target size and target susceptibility is maximized. This product is maximized between the pink and bloom stages of bud development, coincident with the peak in the distribution of ascospore discharge (Fig. 6C). The pathogen effectively copes with this trade-off between a target that is expanding and, simultaneously, becoming more resistant to infection. Nearly one-half year beforehand, the pathogen begins reacting to a series of variable environmental stimuli and does so with the ultimate effect of releasing the bulk of the overwintering inoculum within a 2 -week period during which reestablishment in the canopy of host trees is most likely (Fig. 6D).

Ascospore discharge attributes. The bitunicate ascus of $V$. inaequalis, a characteristic of the subclass Loculoascomycetidae, is composed of a relatively thickwalled and rigid exoascus and a thinwalled, extensible endoascus. When leaf tissue is wet, water moves into the ascocarp either through the ostiole or through the porous ascocarp wall and then into the asci through osmosis (5). Physiologically mature asci (32) then swell and protrude through the ostiole. If the exoascus tip ruptures, the endoascus extends further until the entire structure is approximately twice its original length and protrudes approximately $40 \mu \mathrm{m}$ beyond the ostiole
$(14,15)$. Following the rupture of the endoascus tip, the uppermost spore is forcibly ejected (37,82). Each successive spore within the ascus is discharged after pausing briefly at the ascus tip. The osmotic nature of the mechanism of ascospore discharge results in a slowing of the process at low temperatures (78), presumably through effects on membrane permeability and biochemical processes.

The movement of the ascus from within a closed, protective, and opaque ascocarp into the atmosphere nearly $40 \mu \mathrm{m}$ above the leaf surface is a significant feature of the process of ascospore discharge in $V$. inaequalis and creates an opportunity for several interactions between the ascus and the external environment. The absence of light, specifically far red light from 710 to $730 \mathrm{~nm}$, is known to suppress ascospore discharge in $V$. inaequalis $(14,15,34)$. However, the suppression of ascospore discharge during darkness is not absolute. For example, senescent pseudothecia (i.e., those remaining after $90 \%$ or more of the season's total inoculum has been discharged) may freely discharge ascospores during darkness (34). Additionally, airborne ascospores have occasionally been trapped following dew at extreme northern latitudes (77). However, in the vast majority of cases, airborne ascospores are detected by volumetric spore traps, and then primarily during daylight hours $(34,54)$ (Fig. 7).

Why should $V$. inaequalis evolve such an elaborate mechanism to restrain the discharge of ascospores during darkness? What possible selective advantage could this confer upon the pathogen? Recognizing that this is speculative, we propose that the requirement of light for ascospore discharge restricts the discharge of ascospores into dew films. Dew forms frequently during the period when ascospores are maturing (24). The typical atmospheric conditions that lead to dew formation are clear,

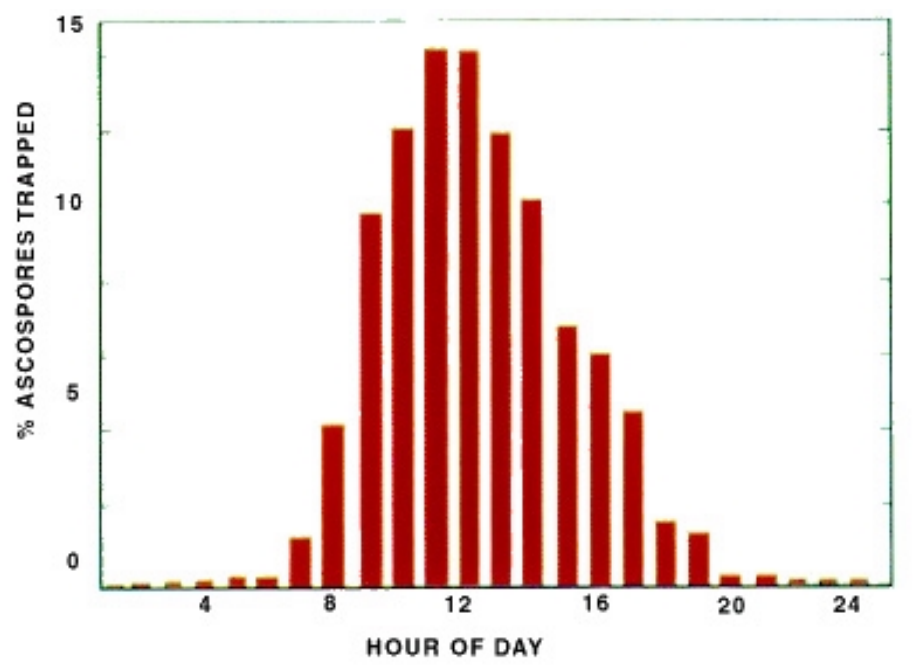

Fig. 7. Four-year means of the percentage of ascospores trapped per hour during 1981 to 1984 in an orchard with high ascosporeic inoculum in New Hampshire (54). 
relatively cold nights during which temperatures must fall substantially below the dew point to cause a heavy dew film on leaf litter. Dew films may form abundantly on subtending leaf litter, while substantial portions of tree canopies above remain relatively dry. Dew formation is also associated with still air conditions and relatively thick boundary air layers, both of which work against escape of ascospores from the leaf litter. Additionally, the thickness of dew films may exceed the extent of ascus emergence beyond the ostiole (ca. 40 $\mu \mathrm{m})$, resulting in discharged ascospores becoming trapped within the dew film. This entrapment is supported by two lines of evidence in previous literature: (i) with the exception of a single study from Norway (77), airborne ascospores are rarely trapped during periods of dew, and (ii) ascospores have been found abundantly in the film of dew on leaf litter without accompanying airborne catches $(54,57)$.

Fair weather begets dew and also generally follows dew formation. What, then, would be the typical fate of an ascospore discharged during darkness? There would seem to be little selective advantage to suppressed ascospore discharge during darkness if only rain were considered. However, ascospores might face all of the above-enumerated obstacles to establishment on the host during dew: (i) relatively low temperatures during the predawn hours, (ii) entrapment in thick water films on the leaf litter, (iii) relatively poor atmospheric conditions for aerial dispersal from the leaf litter, (iv) deposition on dry leaves of the host, despite wetness of the subtending leaf litter, and (v) if the tree canopy were initially wet by dew, then rapid drying after sunrise due to fair weather. The suppression of ascospore discharge by darkness has the ultimate effect of conserving the primary inoculum for discharge during the most favorable conditions for infection. Some opportunity for discharge is lost during night rains, but the cost of this may be outweighed by the counterbalancing (and more frequent) avoidance of discharge during dew.

Ascospore dispersal attributes. Once discharged during a suitable rain event, the ascospore's next challenge is dispersal to the host. Ascospores are produced abundantly in the leaf litter, and beneath a severely diseased tree the ascospore dose may exceed several million per square meter of ground (28). The ascospores must accomplish the task of reestablishing the parasitic relationship after a period of host dormancy. To do this, they must first either return to the canopy of their original hosttree in spring or disperse to another suitable host at some more distant location. $V$. inaequalis appears to possess traits that are primarily adapted toward short-range dispersal, with some limited longer-range dispersal.

Infected leaves drop to the ground beneath an ideal host. The tree is susceptible (otherwise there would not be infected leaves beneath it) and it is perennial. However, without capacity for longer-range dispersal, the death of the original host tree might spell the end of the pathogen population in the fallen leaves. It is important to keep in mind that $V$. inaequalis did not evolve in an orchard with multiple and contiguous hosts. In its natural environment, there would presumably be selection for effective short-range dispersal to the original host tree, but with some eventual need for dispersal of spores to neighboring trees at uncertain distances. In addition to dispersal of spores, short-range dispersal of leaves by wind may move leaves to nearby trees, and this may have played a role in dispersal of the pathogen in natural environments.

The traits that are generally associated with short-range dispersal of spores are easily enumerated for $V$. inaequalis. The ascospores are produced abundantly but are discharged during a time when mass transport is strongly downward (i.e., during rain). They are relatively delicate structures, without the thick cell walls or heavy melanization of the conidial state to protect them from desiccation or UV radiation. Despite the apparent lack of traits that confer competence for longer-range dispersal, recently developed models indicate that some $V$. inaequalis ascospores would be transported 2 to $5 \mathrm{~km}$ from point and area sources of inoculum (4), and presumably at such distances desiccation and irradiation are not significant mortality factors, given that the dispersal may occur in a matter of minutes at this range, and often during a rain event. The exact number of such ascospores that survive, are deposited on host tissue, and eventually cause disease at such distances remains unknown. Presently, scab is generally managed based upon assessments of potential ascospore dose within an orchard (51).

Summary: saprophytism. $V$. inaequalis has a highly specialized saprophytic phase which allows it to survive the intercrop period of its deciduous perennial host (Table 1). Leaf death is the signal that initiates growth into the internal tissues. Thermal optima for development change during overwintering to reflect declining and then increasing temperatures. A number of attributes have evolved that increase the probability of successful reestablishment after the host resumes growth in spring. Negative geotropism orients the ostiole toward the atmosphere. Ascospores mature within days of bud break, even though the ascocarp is initiated 5 months earlier and, indeed, the bulk of the population matures when the product of leaf size and susceptibility are maximized, thereby maximizing the probability of infection. Suppression of ascospore discharge during darkness may conserve inoculum that would otherwise be wasted during dew periods. Ascospore dispersal is primarily a short-range process evolved before cultivation of apple, and it appears to be adapted toward getting the ascospores from the leaf litter back to the

Table 1. Traits of Venturia inaequalis and possible relationship to parasitic fitness

\begin{tabular}{ll}
\hline Trait & Possible role \\
\hline Saprophytism in ascigerous state, with ascospores being parasitic & $\begin{array}{c}\text { Survival of host dormancy on shed, dead leaves and later establishment } \\
\text { on new, living leaves }\end{array}$ \\
$\begin{array}{l}\text { Shifting thermal optima and extended period of ascocarp development } \\
\text { Lurvival of extended period of host dormancy } \\
\text { Maximizes ascocarp numbers as mean daily temperatures are declining; } \\
\text { maximizes ascus numbers at low temperatures during late winter to } \\
\text { early spring } \\
\text { Increases rate of ascospore maturation as mean daily temperatures in- } \\
\text { crease }\end{array}$ \\
Higher thermal optimum during later ascocarp maturation & $\begin{array}{c}\text { Discharge of ascospores toward atmosphere; reorientation of ascocarp } \\
\text { in disturbed leaf litter }\end{array}$ \\
Negative geotropism in ascocarp formation & $\begin{array}{c}\text { Conservation of ascosporic inoculum during dew periods when envi- } \\
\text { ronmental conditions would not favor dispersal and infection } \\
\text { Ascospores discharged at host developmental stage most favorable to } \\
\text { contact and infection }\end{array}$ \\
\hline
\end{tabular}


tree from which the leaves dropped. Nonetheless, their abundant production and discharge during turbulent rain events results in some longer-range dispersal.

\section{Parasitism}

The arrival of ascospores on susceptible host tissue is a signal event in the life of $V$. inaequalis and marks the immediate switch from months of saprophytism to growth as an active parasite, with all of the attendant interactions with a living, growing, and resisting host. As with the saprophytic stages, the pathogen displays a remarkable degree of adaptation toward the host, and vice versa. We now consider those features that characterize this association.

Ascospores are covered with a mucilaginous sheath and adhere readily, even to the wet but hydrophobic waxy surfaces of apple leaves and fruit. Once deposited, they rapidly attach, probably by a mucilaginous coat (Fig. 8), and germinate. The pathogen is particularly well-adapted to infect the host at relatively low temperatures. In fact, the most recent studies have illustrated that infection by both ascospores and conidia can take place in as little as 30 $\mathrm{h}$ at $1{ }^{\circ} \mathrm{C}$ (78). All steps in pathogen development and infection are slowed by low temperatures, but unlike many biotrophs such as powdery mildew pathogens, $V$. inaequalis is a very active pathogen at low temperatures.

Germination proceeds so long as free water is present on the host surface. An appressorium develops shortly after the ascospore germinates (80), followed by the growth of a penetration peg that pierces the cuticle but not the epidermal cell wall (76). During parasitism, $V$. inaequalis exists solely as a subcuticular parasite, wholly external to the host epidermal cells (Fig. 1). How the subcuticular stroma effectively extracts what it needs from host cells in such a noninvasive fashion without benefit of specialized absorptive structures such as haustoria is not known.

Ontogenic resistance. Despite its enigmatic means of sustenance, the pathogen

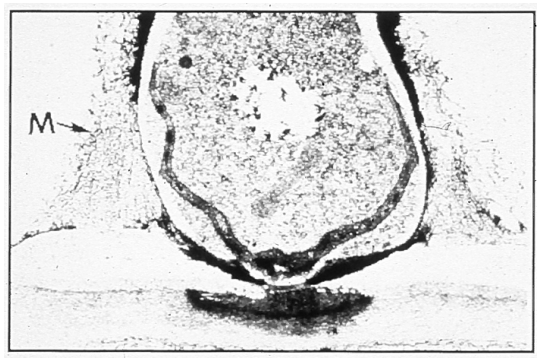

Fig. 8. Transmission electron micrograph showing reaction of the cuticle and host cell wall beneath the penetration pore of a germinated ascospore of Venturia inaequalis on the leaf surface and mucilage believed to anchor the ascospore to the host surface. $\mathrm{m}=\mathrm{mu}$ cilage (76). can increase its biomass considerably in a period of 7 to 10 days and ramify an area up to $2 \mathrm{~cm}$ in diameter before conidiophores erupt through the cuticle to produce the conspicuous olivaceous lesions that typify the disease. This rapid growth, however, occurs only in leaves that have not fully expanded. A counterbalance to the susceptibility of emergent and expanding leaves is ontogenic (age-related) resistance that is expressed in fully expanded leaves (Fig. 9). Ontogenic resistance increases rapidly with leaf age and is strongly exbloom (19) and in leaves of vegetative shoots more than three to four nodes removed from the shoot apex $(19,20)$.

Ontogenic resistance is one of the most significant features of the natural development of apple scab in the wild. For the pathogen, highly susceptible tissue is present throughout most of the growing season, and indeed, as was previously mentioned, the flush of young cluster leaves coincides with the flush of ascospores produced in early spring. Once the tree has bloomed, the preponderance of foliage is much more resistant to infection, but so long as shoot growth continues, there will remain a small proportion of the canopy that is highly susceptible to infection. However, the bulk of the foliage will be quite resistant, and although not immune, it will persist and continue to function despite relatively heavy disease pressure.

Ontogenic resistance not only affects the absolute number of infections, but also the time that it takes for a lesion to appear and the duration of time over which additional lesions will appear. Temperature has also been shown to affect the latent period, but the effect is relatively small compared with the impact of leaf age on the latent period. For example, a temperature change from 20 to $10^{\circ} \mathrm{C}$ will increase the latent period pressed in cluster leaves shortly before

from approximately 14 days to 21 days in highly susceptible leaves. In comparison, the number of visible lesions can more than double between 21 and 80 days after infection in leaves that are older, and hence express ontogenic resistance more strongly (21).

Once conidia are produced, the disease spreads mainly within the canopy of the infected tree. The subcuticular stroma may appear as a discrete lesion, or it may be an inconspicuous network of diffuse stromatic cells, with each giving rise to widely dispersed conidiophores. In general, the older and more resistant the leaf, the more diffuse or atypical the colonization that results $(10,54)$. Irrespective of the lesion type, conidia are released into a water film that covers the conidiophore. If this is a light film of dew, the conidia may be dispersed on the same leaf and thereby increase disease severity on that leaf. During rain, the conidia are splash-dispersed to other leaves, generally downward in the canopy from the site of their production. Rarely are conidia detected as airborne spores outside of the drip line of the tree, even when they are trapped in extremely high densities in rain splash directly beneath the tree.

Subcuticular growth of the parasite is extremely slow in mature living leaves, but when the leaves abscise in autumn, the fungus returns to the saprophytic phase and growth accelerates, no longer under the restraints of ontogenic and horizontal resistance in a living host (84).

Summary: parasitism. There is a period in early spring when ascosporic infections are established in the canopy. This is followed by a protracted period of local spread in which additional tissue (on the same leaf and on additional leaves) is infected by conidia. Ascospores function to establish new infections in the canopy after

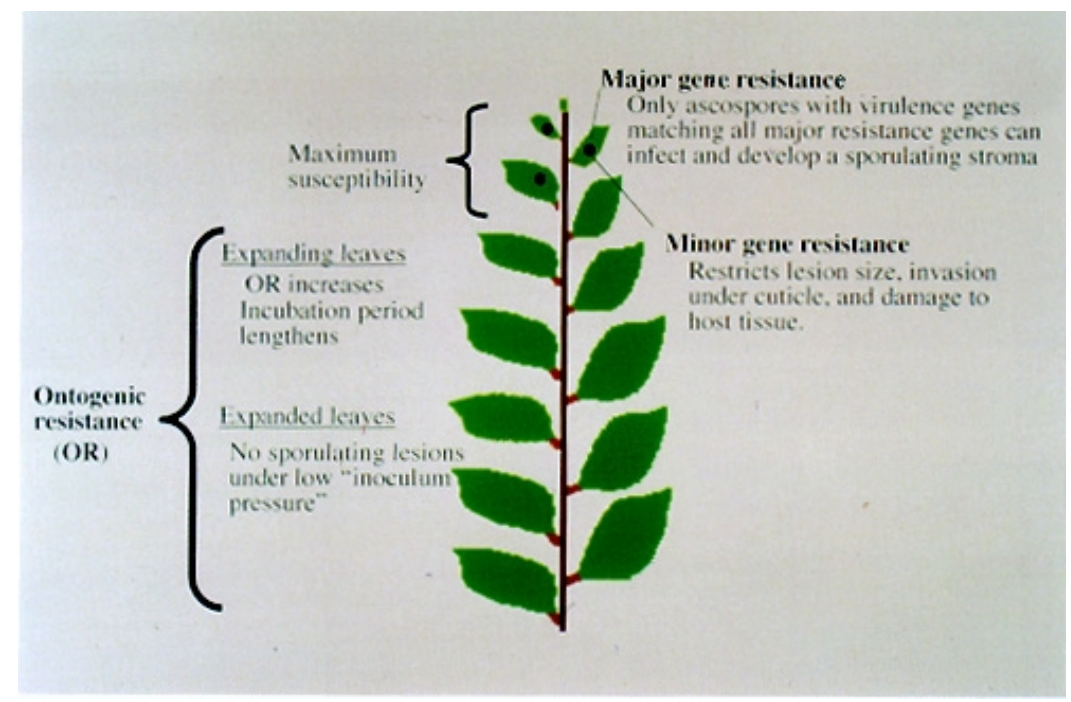

Fig. 9. Diagrammatic representation of ontogenic, major gene (vertical) and minor gene (horizontal) host resistances to Venturia inaequalis in an apple extension shoot with respect to incubation period and expression of symptoms. 
overwintering beneath the host on shed organs; yet they retain some capacity for long-distance dispersal in the event that the original host-tree dies. Conidia function to increase the amount of foliar tissue colonized by stromata and to increase the likelihood of pairing of compatible mating types on the same leaf. Rarely do trees defoliate or suffer loss of photosynthetic area that is lethal to trees. While fruit may be infected and unmarketable, they are still produced in abundance and, more importantly, contain viable seeds. In view of all the interactions and associations discussed, $V$. inaequalis and its host have coevolved to a high degree. The pathogen is committed to a life of parasitism and requires the host to survive and reproduce; yet the host, although measurably damaged, does not die from the association, and despite being parasitized continues to survive, grow, and reproduce. Given this seemingly benign association, how has this level of genetic equilibrium come about, how has mankind's manipulation of the natural system affected the relationship between host and parasite, and what has been the resultant impact on epidemic progress?

\section{Coevolution}

Nelson (59) speculated that the initial resistance of a host to a new parasite occurred by a genetic change at a single locus and that the resistance reaction was probably a hypersensitive response. The parasite population then evolved by the selection of a strain (race) that was virulent to the thenresistant host. Short-term parasitic success and host biological success were selected against in favor of long-term success: selection pressure favored host and parasite genotypes that were compatible. For example, a virulence allele that resulted in a response that killed the host would, over time, be selected against because the susceptible host population would be eliminated, or a resistance gene that conditioned a hypersensitive reaction would be ephem- eral because it would place infection pressure on the selection of a virulence allele that allowed the parasite to become established. Thus, coevolution continued in a stepwise, gene-for-gene manner that resulted in the accumulation of many resistance genes and corresponding virulence genes. As coevolution progressed, the genetic changes conditioned more subtle response.

Ultimately, a genetic equilibrium was achieved that each could live with and, according to Nelson (59), further genetic changes incorporated into a population of the host or parasite would condition no more than slight improvements in host or parasite fitness. Was this the process by which apple and $V$. inaequalis coevolved to their level of genetic equilibrium (compatibility) at the beginning of the modern era of commercial apple production? We can't say with certainty that it was, but research has provided us with some insights that suggest it was.

Major (race-specific) genes conditioning the hypersensitive, "pit-type" reaction mentioned by Nelson (59) as a likely initial response to attack by a new parasite are present in Malus species and in many old domestic apple cultivars and progenies from them, but two backup resistance systems (race-nonspecific and ontogenic) combine to limit infections when major gene resistance is overcome (Fig. 9), as discussed in the following sections.

Major (race-specific) genes for resistance and corresponding virulence genes that exhibit gene-for-gene resistance have accumulated in apple and $V$. inaequalis. Much of the early work in Europe $(1,2,67-$ $72,83,84)$, the United States $(41,44,46,61)$, and Canada (39) demonstrated variability of the reaction of susceptible cultivars and crabapples toward $V$. inaequalis. More detailed investigations confirmed the earlier observations and studies: particular isolates attacked the cultivar from which they originated more severely than they attacked other cultivars $(62,74,84)$. In the mid-1900s, genetic analysis became popular, and genes for pathogenicity (defined today as virulence/avirulence genes) were identified that had selectively overcome resistance genes in crabapple and particular selections of domestic apples. The segregation for resistance to scab in the progenies of controlled crosses with $M$. atrosanguinea, M. floribunda, and M. micromalus revealed that resistance (hypersensitive reaction) in each species was conditioned by a single gene in the heterozygous condition (reviewed in 51, pp. 81-86). Seven loci in $V$. inaequalis conditioning avirulence/virulence to several domestic cultivars were identified (13), and 19 pathogenicity genes (diallelic virulence/ avirulence genes) were identified in crabapples $(6,7,12,41-43,85)$.

Ephemeral resistance genes in domestic cultivars. Many of the species and subspecies (crabapples) that comprise the genus Malus (49) intercross freely (selfincompatibility is the rule) in the natural ecosystem, and some that were very likely included in the early development of the domestic apple, e.g., M. pumila, M. sylvestris, and M. baccata (16), also have major gene resistance to $V$. inaequalis. All domestic cultivars with lineage to these species and subspecies would be expected to have a combination of these major genes.

Knowledge acquired in the 1940s and 1950s that many older domestic cultivars such as McIntosh, Yellow Transparent, Haralson, and Red Astrachan susceptible to scab carried several alleles that conditioned avirulence/virulence to $V$. inaequalis was suggestive that all other susceptible apple cultivars with lineage to the same resistance pool also carried the ephemeral differential resistances. Nevertheless, the notion that susceptible "modern" domestic cultivars lack major resistance genes found wide consensus.

All the ephemeral resistances putatively present in Malus $\times$ domestica were forgot-

Table 2. Macroscopic symptoms ${ }^{\mathrm{a}}$ induced by selected differential isolates of Venturia inaequalis on domestic apple cultivars ${ }^{\mathrm{b}}$

\begin{tabular}{|c|c|c|c|c|c|c|c|c|}
\hline \multirow[b]{2}{*}{ Origin of isolate } & \multicolumn{8}{|c|}{ Test cultivar } \\
\hline & A. Reinette & Boskoop & Glockenapfel & $\begin{array}{l}\text { Golden } \\
\text { Delicious }\end{array}$ & Jonathan & Gravenstein & R. Champagne & Spartan \\
\hline Ananas Reinette & 3 & 1 & 0 & 2 & 0 & 0 & 0 & $-^{c}$ \\
\hline Boskoop & 0 & 2 & 0 & 0 & 1 & 0 & 1 & 0 \\
\hline Glockenapfel & 2 & 1 & 4 & 3 & 1 & 0 & 1 & - \\
\hline Golden Delicious & 1 & 0 & 1 & 4 & 0 & 0 & 1 & - \\
\hline Jonathan & 0 & 0 & 0 & 0 & 3 & - & 0 & - \\
\hline Gravenstein & 0 & 0 & 0 & 0 & 0 & 4 & 0 & - \\
\hline Maigold & 2 & 3 & 0 & 3 & 3 & - & - & 0 \\
\hline Reinette de Champagne & 0 & 1 & 0 & 1 & 2 & 0 & 4 & - \\
\hline Spartan & 3 & 4 & 4 & 4 & 4 & 4 & 4 & 4 \\
\hline
\end{tabular}


ten or, at most, remained a curiosity (35) until recently when it was reported that Golden Delicious carries a differential resistance gene (36) designated $\mathrm{Vg}(9)$, and in another study (75), that there was differential resistance in Boskoop, Golden Delicious, and Spartan. When these findings are considered with the earlier literature, it becomes plausible that many other such ephemeral resistance alleles are present in Malus $\times$ domestica, and that idea has been investigated. Monosporic isolates of $V$. inaequalis were obtained from lesions caused by early-season infections in five orchards across Switzerland and tested on a range of cultivars (Golden Delicious, Ananas Reinette, Boskoop, Glockenapfel, Jonathan, Gravenstein, James Grieve, Maigold, Reinette de Champagne, Spartan, and Yellow Transparent). Differential interaction with selected isolates was shown for all cultivars (48). Avirulent and virulent isolates could be determined for each test cultivar, and the pattern corresponded to the classical vertical (differential) resistance scheme. This led the authors to conclude that functionally different resistances are present in commercial apple cultivars and that corresponding virulence/ avirulences are present in the pathogen. Table 2 (selected data from 48) shows that all interactions typical for a gene-for-gene relation can be found.

The picture that emerges from this research is that functionally different resistances are present in every cultivar and that $V$. inaequalis has corresponding virulence/avirulence genes that can match these resistances: an isolate (spore) cannot successfully attack an apple cultivar unless all of the differential (ephemeral) resistances are matched by the corresponding virulence alleles. Support for this statement comes also from the appearance of races virulent to cultivars bred with major gene resistance to $V$. inaequalis (65).

Interactions between apple and $V$. inaequalis and long-term survival. Survival of apple and $V$. inaequalis over the long term has been achieved through the selection of genes conditioning interactions that allow a variable portion of the local $V$. inaequalis population to develop a stroma and produce conidia after causing only limited damage to apple leaf tissue. However, once the single tree is confronted with the corresponding $V$. inaequalis genotype, limiting secondary buildup of scab is also a requisite for long-term lifelong success of a particular apple tree in the natural system. Apple's minor (race-nonspecific) gene resistance system and its ontogenic resistance are at this stage the main determinants of long-term survival of a tree.

Minor (race-nonspecific) genes and their interaction with $V$. inaequalis genotypes (Fig. 9). Apple has a durable, racenonspecific (horizontal) quantitative resistance system thought to be comprised of many genes that condition a basically compatible interaction in which the parasite produces a sporulating stroma with little noticeable damage to host tissue. The genes in this system condition the subtle responses Nelson (59) predicted would occur in the long process toward achieving genetic equilibrium. The significance of this resistance system is threefold: it limits the extent the parasite can colonize and damage a susceptible host, it is effective against all races of the parasite, and it is durable. Its interactions with a pathogen genotype also determine the length of the incubation period and the amount of sporulation, two important fitness attributes that affect the rate of scab buildup. This quantitative resistance may be expressed to various degrees and is postulated to be determined by the additive effect of a variable number of quantitative trait loci.

Ontogenic resistance and susceptible tissue (Fig. 9). Ontogenic resistance reduces the number of infections, while still allowing $V$. inaequalis to be successful, by limiting the amount of susceptible tissue on each shoot almost entirely to the youngest two or three leaves, as described above. It apparently becomes inoperative in autumn, perhaps due to processes involved in leaf senescence, but this is not a direct threat to the host. In a nonbearing seedling, ontogenic resistance would slow scabinduced defoliation to nearer the time of normal leaf fall, thus lessening the weakening effect, and possibly death, an early defoliation might have on a young seedling. In a bearing tree, fruit is already produced by autumn, and the production of seed is how success (survival) in apple is measured.

The nature of ontogenic resistance is not known, but it apparently is durable because we know of no report that it was not operative in matured leaves on an actively growing shoot under natural conditions. The apparent absence of ontogenic resistance in autumn allows for the buildup of successful parasite genotypes in preparation for sexual reproduction after leaf fall. This may lessen the selective pressure for genotypes that can overcome ontogenic resistance and, if so, may account in part for the evolutionary durability of ontogenic resistance.

\section{Strategies to Achieve Genetic Equilibrium (Compatibility)}

Reproductive strategy in apple that provides the genetic diversity to cope with genetic changes in $V$. inaequalis. The production of seed with new combinations of major resistance genes is the key to the success of major gene resistance in natural Malus ecosystems. Each seed has a distinct combination of major resistance genes, and an ascospore can infect a seedling and develop a sporulating stroma only if it has a matching set of virulence genes. The significance of major gene resistance is that many ascospores do not have the matching combination of virulence genes: the number of sporulating lesions on any seedling will be proportional to the number of ascospores with the correct combination of virulence genes. The seedling with major resistance genes that have the fewest matches with ascospore virulence genotypes will be the most resistant to that parasite population and the most likely to survive attack by $V$. inaequalis. Before mankind interfered with the natural ecosystem, sexual reproduction, along with horizontal and ontogenic resistance systems, was how apple kept the infection rate low enough to survive, i.e., for a seedling to grow and produce fruit.

Major resistance genes common to both parents is not desirable for apple because corresponding virulence alleles in the parasite population will become fixed, i.e., be present in all ascospores. Outbreeding (self-incompatibility) is the host strategy to diversify, as much as possible, the alleles that reduce parasite fitness. If apple were self-compatible and a cultivar were susceptible to scab, then all siblings (seedlings) of that cultivar (theoretically) would be susceptible to all ascospores produced from infections that occurred on that cultivar just as (theoretically) all conidia produced in lesions on that cultivar would infect that cultivar. Virulence alleles would become fixed in the pathogen population, and all seedlings would be susceptible. This relationship would not change until an allele appeared in the host that conditioned an incompatible response. In the natural ecosystem, the host tree has many half- and full-siblings growing nearby, and any sibling with a unique combination of resistance alleles will be best fit. In a commercial orchard, adjacent trees are likely to have an identical resistance genotype.

$V$. inaequalis reproductive strategies that provide the genetic diversity to cope with genetic changes in apple (Fig. 10). For $V$. inaequalis to survive in the natural ecosystem, some ascospores must establish new infections when tree growth is renewed in spring. This is not a problem if the tree infected the previous growing season is still alive, because at least some ascospores will have the combination of virulence alleles needed to infect and produce a sporulating stroma. Survival is threatened if the tree dies, because apple is an obligate outbreeder and each sibling growing nearby will have a unique combination of race-specific resistance genes that an ascospore can overcome only if it has a matching set of virulence genes. Crossing experiments in the 1940s $(13,40-42,44)$ using $V$. inaequalis strains with specific virulence to apple cultivars carrying differential resistances showed that new combinations of virulence genes do occur in ascospores and that the expression of pathogenicity (defined today as virulence) of the parasite is determined by host and pathogen genotypes. Thus, to increase the 
chance that a half- or full-sibling in the vicinity produced by the dead tree, or any other apple trees nearby, will be infected, the production of ascospores is the strategy that has assured survival. Once a few ascospores have established sporulating lesions, the successful genotypes will build up through secondary cycles of asexually-produced conidia. If two different mating types infect the same leaf and sexual reproduction occurs after leaf fall, the parasite has been successful.

\section{Cultivar Relative-Resistance Can Change}

A cultivar's susceptibility/resistance to scab may vary from one region to another, or even at different sites within a region. This was first reported in 1899 by Aderhold (2), who concluded that the resistance of a particular cultivar depends on its interaction with the specific fungal population present. It has also been observed that a cultivar's resistance changed noticeably within an orchard or region. Golden Delicious trees in a secluded planting with new resistant cultivars (Freedom and Priscilla) did not develop scab for the first 5 years, even though an old, large, susceptible apple tree that became severely scabbed each year was only a few meters away, but subsequently these Golden Delicious trees were noticeably scabbed if not protected with fungicide (C. Gessler, personal observation). Earlier, in England, Bramley's Seedling was listed as scab-resistant, but by the early 1930s it had become highly susceptible (38). In the northeastern United States, Baldwin was considered highly resistant to scab in the late 1800 s and early 1900s, and Baldwin trees grown among very susceptible McIntosh trees would have very little scab even though the McIntosh trees were severely scabbed. By

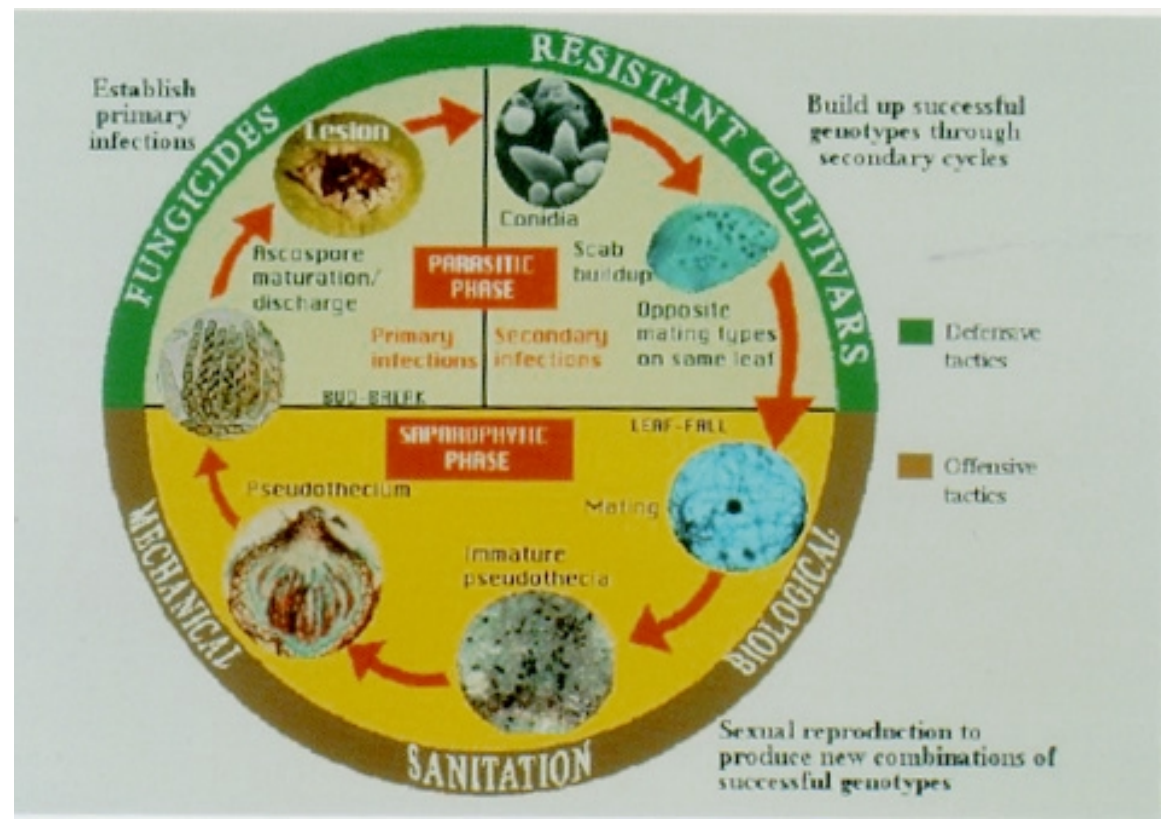

Fig. 10. Parasitic and saprophytic phases in the life cycle of Venturia inaequalis diagrammed to identify the three reproductive strategies and practices to control each reproductive strategy. genetics research explains why Prima became susceptible to scab: until a new strain (race) appeared that had a virulence allele matching the Vf resistance allele, there were no genotypes in the pathogen population that could successfully infect Prima. What was revealed when Prima became susceptible to scab in that orchard is that (i) a major resistance gene is ephemeral, (ii) when the gene is overcome, it is no longer identifiable in that orchard even though it is present, and (iii) although it is not known how many races were in that orchard, one new race was added. After nearly a century, Wallace's speculation in 1910 that a new strain of $V$. inaequalis was responsible for the severe scab that occurred on very resistant Baldwin trees was given strong support.

Prima's becoming susceptible to scab was very likely a reenactment of an event that had occurred many times during the coevolution of apple and $V$. inaequalis. If so, considering the knowledge mentioned above, it is plausible that each cultivar has a unique combination of many ephemeral major resistance genes and that there are many races of $V$. inaequalis, as Shay et al. (73) noted nearly 40 years ago: "Few, if any, of the commercial apple varieties are resistant to a sufficient proportion of the total US or European population of biotypes of $V$. inaequalis to warrant their use as resistant parents in apple improvement," therefore "there has been no useful purpose to be served by describing and naming the hundreds of different physiologic races that can be differentiated by these hosts." It follows that the proportion of pathogen spores in an orchard that can infect a cultivar will be an important determinant of the cultivar's relative resistance to scab expressed in that orchard. This would explain why a cultivar's relative resistance to scab may differ from one orchard to another within a region or from one region to another, and recent research seems to bear this out. When 21 single conidial isolates, seven each from three cultivars (Boskoop, James Grieve, and Spar$\tan$ ), were pooled in equal amounts and inoculated onto the three cultivars, the only isolates recovered from each cultivar after three asexual cycles on each cultivar were those that were originally isolated (74). The virulence allele frequency toward each cultivar had changed from 33 to $100 \%$. There was also a dramatic change of isolate frequency within each subpopulation. In all three cases, over $90 \%$ of the subpopulations were composed of two genotypes, indicating the interaction system is highly complex. In addition to the relatively simple virulence/avirulence differential-resistances relationship that exerts selection pressure, genotypes were apparently being selected that more or less fit the particular conditions, thus contributing to further diversify the pathogen population.

The research confirmed that a cultivar does not allow survival of genotypes that do not have the correct matching virulence 
alleles, as mentioned above. It is clear from what we have presented that race composition in an orchard is an important factor determining the relative resistance of a cultivar. It has become evident from another study (48) in Switzerland that cultivar composition in an orchard provides selection pressure for pathogen genotypes. In an orchard of a single cultivar, all isolates tested were virulent to the cultivar present. Other virulence genes were present at low frequency, and some virulences were absent (or below the detection level). In an orchard with many cultivars, no virulence was fixed (present in all isolates tested), and the frequency of isolates virulent on each cultivar reflected the quantitative presence of the various cultivars. Generally, the highest frequency of any additional virulence was found in populations from orchards with a cultivar mixture; the lowest frequency of any virulence (excluding the matching virulence) was found in populations in orchards of a single cultivar. A high proportion of isolates originating from cultivar mixtures with additional virulence to Golden Delicious reflects the past and present importance of this cultivar in Switzerland and in Europe (36 and 32\%, respectively) of traded apples (58). In addition, $24 \%$ of the commercial orchards are planted with cultivars having Golden Delicious as one of the parents.

The results of these studies provide insights for potential new directions in scab management. The possession of multiple virulence genes in a population gives ascospores a selective advantage in cultivar mixtures, whereas in monoculture, only one virulence pattern is needed for successful reproduction. In the natural ecosystem, the variation in resistance gene composition among apple individuals counteracts this to reduce scab incidence. If this strategy is effective in the natural system, why wouldn't it be successful in commercial apple production?

Computer simulation models with apple and $V$. inaequalis predicted a reduction in lesions of approximately $70 \%$ after six asexual generations in a mixed compared with a pure orchard (11), and preliminary results in an orchard study are in general agreement (C. Gessler, unpublished). Scabbed fruit on Golden Delicious-only rows was reduced from $20 \%$ (year 2000), $66 \%$ (year 1999), and 41\% (year 1997) to 1, 27, and 9\% in Golden Delicious, Elstar, and Pinowa rows, respectively. It does not appear that the mixed-cultivar strategy alone would provide sufficient commercial control of scab, but reducing the infective inoculum by $50 \%$ could have value in a scab management program if integrated with other management strategies. For example, reducing the ascosporic inoculum $50 \%$ with sanitation and $70 \%$ in a mixedcultivar planting would, theoretically, reduce the ascospore dose by approximately $85 \%$. This reduction in ascospore dose might reduce scab to a level that would be manageable with less fungicide than currently recommended (see management section).

\section{Disease Management}

Sexual reproduction: the pathogen's Achilles heel. $V$. inaequalis is apparently committed to parasitism, because it is not known to live as a saprophyte in nature other than in fallen leaves that had been infected before the leaves fell. Nevertheless, the saprophytic phase is critical to the survival of $V$. inaequalis. It is closely synchronized with apple's dormant period (Fig. 5), a major reason $V$. inaequalis is a successful parasite on apple. However, apple's dormant season is also the most perilous time for $V$. inaequalis. Sexual reproduction provides the linkage from one growing season to the next, so the first few weeks after leaf fall, when the sexual stage must be initiated before the onset of freezing temperatures, is the parasite's most critical period for survival (Fig. 10). If the sexual stage doesn't occur at that time, the life cycle will end when the leaf litter is decomposed. Preventing or disrupting this vital, vulnerable stage in the pathogen's life cycle is an obvious control strategy. Why, then, have control programs relied almost entirely on fungicides to protect the trees against primary and secondary infections rather than on practices that attack this weak link in the pathogen's life cycle? The answer is found in the origin of scab control programs.

\section{The Origin of Scab Control Programs}

Apple scab became a problem that needed to be controlled in the mid-1800s when the modern era of intensive apple production was initiated. The new horticultural practices set the stage for a scab epidemic, and scab became prevalent in European orchards in the late 1800 s as a result of several years of weather highly favorable for scab. By coincidence, Bordeaux mixture, the first widely used fungicide, was developed in France at that time to control downy mildew of grape. Bordeaux mixture was soon tested for scab control, and repeated applications reduced the scab problem (60).

The success with Bordeaux mixture established the strategy for scab control throughout the twentieth century. First there was the development of more efficacious, less phytotoxic inorganic fungicides, then the development of synthetic organic fungicides. An arsenal of fungicides with several new modes of action became available, and new spray schedules were developed to utilize their protectant, afterinfection (eradicant), presymptom, and postsymptom activities (reviewed in 51).

The advantage of $V$. inaequalis in modern apple production. Apple culti- vars are propagated vegetatively, and therefore the sexual process that produces seedlings with new combinations of resistance genes, some of which may have greater resistance to the local pathogen population, is circumvented. In contrast, $V$. inaequalis reproduces sexually each year, and each year it has multiple opportunities to infect and reinfect the same cultivar with new genotypes, some of which may have improved parasitic and biological fitness factors. This situation clearly favors change in the parasite, potentially at greater expense to the host, but in what ways has it affected the compatibility that had been achieved between $V$. inaequalis and apple?

There is no evidence that $V$. inaequalis, considered as a population entity, has become more aggressive. That is, scab lesions are no larger today than they were $100+$ years ago, and the pathogen is still restricted to the subcuticular space until leaf fall, with little noticeable damage to underlying cells. What, then, has been the major effect of modern apple production practices on scab epidemiology? We suggest it is primarily an increase in the proportion of successful infections, i.e., an increase in infection efficiency, caused by an increase in the proportion of compatible ascospores in an orchard or region. Data from Sierotzki et al. (74) are suggestive that even between compatible genotypes, some genotypes may have a higher infective and reproductive capacity and are able to displace weaker genotypes during asexual multiplication on the same host. This cannot be proved because there are no data to compare epidemic rates in modern and earlier orchards with similar ascospore dose and infection conditions, but an analysis of horticultural practices introduced into apple production over the past century leads us to that conclusion.

Herbicide-treated strips within tree rows and repeated mowing provide an unobstructed pathway for discharged ascospores to reach the tree canopy, and semidwarfing and dwarfing rootstock and new pruning techniques place the tree canopy close to the inoculum source (Fig. 3). These practices allow a greater proportion of discharged ascospores to reach susceptible tissue and, consequently, increase the number of successful infections for a given ascospore dose. Considering the genetic uniformity in modern orchards planted with one or very few cultivars, if we were to design an apple orchard to optimize ascospore dispersal to a host that most of the ascospore population can infect, what more could we do? The effect of these horticultural practices on scab epidemiology was not readily recognized because new fungicides, new strategies for applying fungicide, and improvements in application technology had kept pace with the increased demands these practices unknowingly were imposing on scab control. 
Although there is no direct evidence that modern orchards are under greater disease pressure (more vulnerable to scab) than orchards 100 years ago, the severe outbreak of scab that often follows a missed application or incorrect application rate of fungicide does indicate the potential for a scab epidemic that exists in orchards today. In the early 1900s, three fungicide sprays, probably not as efficient as today, provided acceptable control of scab, whereas today missing one spray at the peak ascospore season in a schedule that may include 10 to 18 sprays can result in an unacceptable level of scabbed fruit.

\section{Pathogen Life Cycle: Clues to Management Strategies}

Reproductive success is a key measure of parasitic and biological fitness, and three reproductive strategies help to ensure the reproductive success and thus survival of $V$. inaequalis. Management practices are aimed at disrupting these three strategies (Fig. 10).

Strategy 1: Establish primary infections. Beginning with renewed tree growth after winter dormancy, the first strategy helps to ensure that ascospores with recombinations of successful genotypes the previous season will be deposited on susceptible tissue when infection conditions are likely to exist. This is accomplished by having ascospores mature over several weeks (beginning around bud break), discharge during rain, and disperse (by chance) to susceptible tissue. This strategy continues until around petal fall, after the maximum amount of susceptible tissue has been produced and ascospores are nearly depleted.

Strategy 2: Build up successful genotypes. The second strategy helps to ensure that the two different biotypes required for sexual reproduction are present on the same leaf. This is accomplished by the production of conidia that are splashdispersed from lesions to susceptible tissue, mostly within the same tree canopy. The incubation period is relatively short, usually 2 to 3 weeks, and secondary cycling can occur until leaf fall.

Strategy 3: Produce new combinations of the successful genotypes. The third strategy provides new combinations of genotypes that had successfully infected the host during the growing season, some of which may make the fungus more parasitically and/or biologically fit. This is accomplished when opposite mating types on the same leaf mate soon after leaf fall to produce immature pseudothecia.

\section{Defensive and Offensive Strategies and Tactics}

Two basic strategies have been used to disrupt or stop the three reproductive strategies: a defensive strategy to protect the tree against infection by ascospores and conidia and an offensive strategy to reduce the ascospore dose during the parasite's saprophytic phase (Fig. 10). Defensive tactics have included fungicide treatment and apple's natural resistance. Offensive tactics have included chemical, physical, and biological means to attack the fungus in the leaf litter or to decompose or remove the leaf litter.

Defensive tactics. Protection with resistant cultivars. The most effective tactic to protect the tree has utilized apple's natural resistance. In an orchard planted with a scab-resistant cultivar, no fungicide is needed specifically to control scab because there are no races virulent on that cultivar. However, the resistances bred into scabresistant cultivars have mainly been conditioned by a single gene effective against the local population of $V$. inaequalis that had not coevolved in the presence of this gene. New mutations or migration of compatible genotypes able to overcome this resistance followed by selective pressure for this virulence has resulted in the appearance and buildup of physiological races. To date, this has occurred with the Vf major resistance gene bred into resistant cultivars. Grower concern for the buildup of resistant populations and poor market acceptance of resistant cultivars have kept the acreage of apples planted with resistant cultivars low.

Protection with mixed-cultivars. Coevolution of apple and $V$. inaequalis, as far as we can plausibly reconstruct from the data presented above, provide some insights for potential new directions in scab management. In monoculture, only one genotype with the matching virulence pattern is needed for successful reproduction. Virulence alleles will be immediately fixed, and therefore all ascospores will be potentially able to infect. In the natural ecosystem, the variation in resistance gene composition among apple individuals counteracts this to reduce scab incidence. If this strategy is effective in the natural system, why wouldn't it be successful in commercial apple production? The preliminary results mentioned above indicate in this direction, but such trials need to be made in various locations over long periods.

Protection with fungicides: scab warning system. The main focus of scab control programs throughout the past century has been to protect the trees against primary infections through repeated application of fungicides. The typical program in 1999 centered on a warning system: a weather station to monitor and record the weather variables needed to predict Mills' scab infection periods, software to calculate Mills' infection periods, strategies to apply fungicide based on the distribution and predicted severity of infection periods, fungicide-resistance strategies, and several means to notify the grower of current infection conditions (53). Some programs also included a model to predict the daily progress of ascospore maturation (24). The most advanced programs also included a procedure to predict an orchard's potential ascospore dose and a scab-risk action threshold based on an autumn assessment of foliar scab $(50,52,53)$. All of the models and procedures listed above aid decisionmaking to select and schedule fungicides to protect the tree against infection by ascospores and conidia. Their purpose is not to replace fungicides with other practices; rather, it is to improve the efficiency in using fungicides.

The fungicide schedules developed throughout the past century were designed mainly to protect the fruit. Emphasis was on preventing infections by ascospores, and a final application was recommended around the time of terminal bud set. The intended result, i.e., a very low incidence of scabbed fruit, was achieved, but man unknowingly exacerbated the scab problem because he did not take into account the parasitic fitness significance of secondary infection cycles, which is to increase the chance that a leaf will be infected by opposite sexual biotypes. Not providing chemical protection through the remainder of the growing season allowed scab to build up in autumn, a phase of the pathogen's life cycle that was not fully appreciated until recently (51). As a result, inoculum pressure (ascospore dose) in spring was often much greater than expected. Attacking the pathogen with chemicals in autumn to reduce its overwintering stage was not overlooked, however, nor has the full potential for including eradicant practices in scab management been realized, as discussed below.

Offensive tactics. Keitt, in Wisconsin, and Palmiter, in New York, conducted eradicant studies beginning in the 1920s and continuing to the mid-1940s (reviewed in 51). Their original intent was to explore the idea that by attacking the pathogen on fallen leaves through ground applications, "...a sufficiently drastic reduction in the ascosporic inoculum might ensure the success of the protectant program, even under the most favorable conditions for scab development, and that lessening the severity of the strain on protectant spraying might permit the use of milder fungicides or fewer applications" (45). Their research had immediate success. In 1937 (45), they concluded that “...(i) suitable applications of eradicant fungicides are capable of drastically reducing the ascosporic inoculum and (ii) such reduction greatly retards and ameliorates the development of the disease, especially in the critical period of primary and early secondary infection," and in 1940, Palmiter (63) stated that "...such eradicant treatments can reduce a potentially heavy ascosporic inoculum to such low levels that mild fungicides may be used with comparative safety."

When the eradicant studies were completed in the mid-1940s, it was clear that 
an eradicant treatment enhanced the recommended sulfur program, but it was concluded that "At this stage in the development of ground treatments it is not suggested that growers omit any regular spray applications because of the ground treatment but consider it an extra spray to aid the regular wettable sulfur program clean up a bad scab situation" (64). Thus, even though the studies showed convincingly that acceptable control of fruit scab could be achieved with fewer fungicides in an orchard treated with an eradicant chemical, there was no recommendation to reduce seasonal fungicide sprays in conjunction with a ground eradicant treatment.

It has been 65 years since Keitt and his coworkers stated the basic epidemiological principles that related inoculum density to the rate of scab buildup and the time when intervention with fungicide treatment must be initiated. Yet, at the present time, there are a very limited number of management programs that base their fungicide schedule on a quantitative assessment of primary inoculum in individual orchards or integrate an eradicant treatment with a reduced seasonal fungicide program. The following may explain why. Until recently $(25,26,30)$, (i) all relevant studies were conducted in high-inoculum orchards, (ii) the majority of these studies were concerned with the effect of eradicants on the production of ascosporic inoculum, (iii) only a few studies had considered treatment effects on scab buildup, and (iv) no studies had related treatment effects on the ascosporic inoculum to a reduced fungicide dose through a strategy that adjusted the standard scab fungicide schedule to accommodate the lowered ascospore dose. The recent revival of the eradicant strategy stresses the usefulness of an eradicant program (chemical, biological, and/or cultural sanitation practices) in conjunction with an action threshold for fungicide intervention.

Reduce leaf litter. Practices that reduce the population density of $V$. inaequalis indirectly by their action on the leaf litter may remove the leaf litter, render the leaf litter unsuitable for the saprophytic and sexual activities of $V$. inaequalis that occur in dead leaves, or prevent discharged ascospores from escaping into the orchard air. Examples include (i) physically removing fallen leaves from the orchard by hand or by machinery, (ii) raking and then plowing the leaf litter under the soil, (iii) raking and then burning the leaf litter, (iv) shredding the leaf litter with a flail mower, (v) treating the leaf litter with chemicals that hasten decomposition (by making it more vulnerable to attack or by increasing the population density of decomposers), (vi) treating the leaf litter with microorganisms that decompose the leaves or grow on the leaf surface and physically prevent discharged ascospores from further flight into the orchard air, and (vii) utilizing earthworms to bury leaves (reviewed in 51).
Attack V. inaequalis directly in leaf litter. Practices that act directly on $V$. inaequalis may restrict or prevent pseudothecial production and maturation or prevent ascospore maturation and discharge. Examples include (i) treating scabbed leaves with pesticidal chemicals, nonpesticidal chemicals, or plant extracts that suppress the development of pseudothecia and ascospores or are lethal to the fungus, and (ii) treating scabbed leaves with an antagonistic (e.g., hyperparasitic) microorganism (reviewed in 51).

\section{Integration of Defensive and Offensive Strategies}

The most advanced scab management program in 1999 integrated defensive and offensive management strategies $(50,52,53$, 55,56). In addition to the warning system and models mentioned above, there were action thresholds for orchards predicted to be at high risk, moderate risk, or low risk for scab determined by an autumn assess-

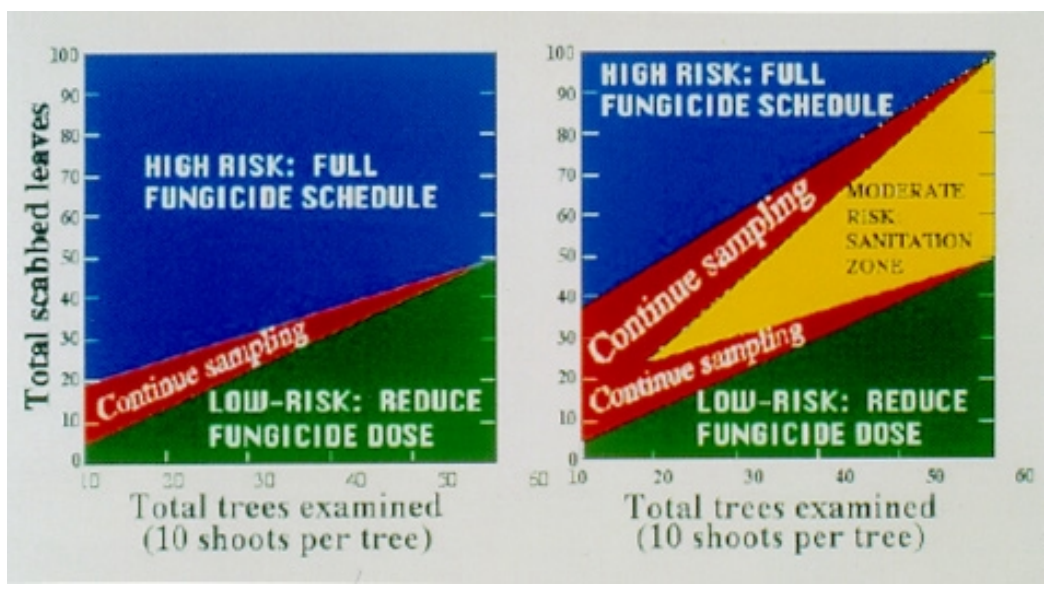

Fig. 11. Scab-risk action threshold (left) and sanitation action threshold (right) for selecting a fungicide and sanitation program to control scab based on an autumn assessment of leaf scab. Sets of 10 trees (10 shoots per tree) are examined until the total scabbed leaves falls within the high-risk or low-risk zone. If sanitation practices are possible, sanitation applied when the assessment falls within the moderate-risk zone will lower the risk to the low-risk zone.

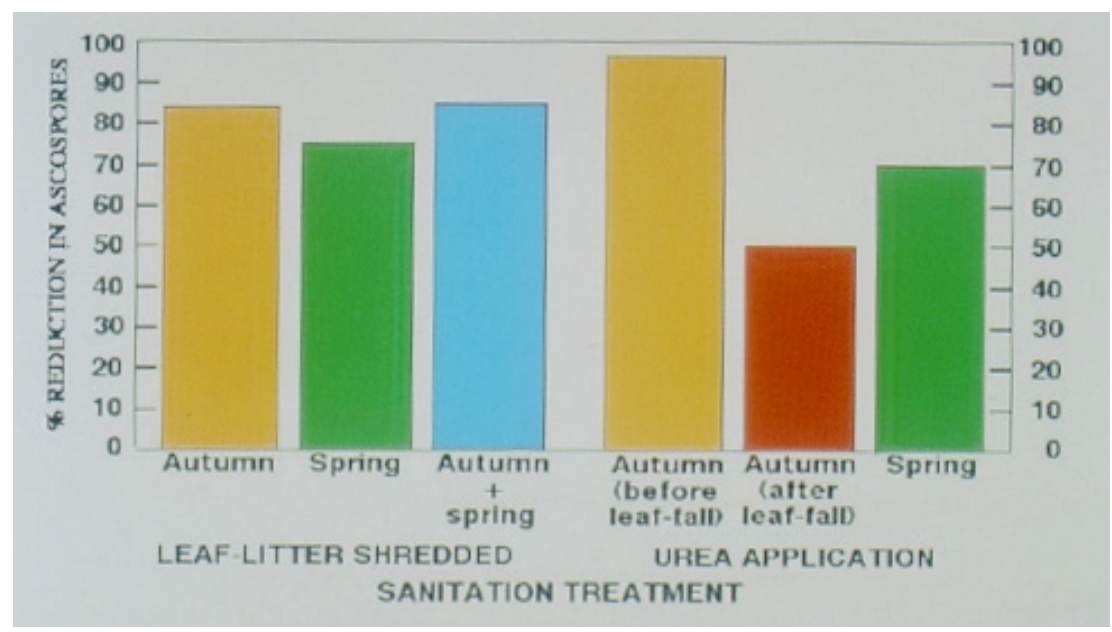

Fig. 12. Percent reduction in ascospores trapped above leaf litter that had been shredded or treated with urea compared with ascospores trapped above untreated leaf litter (56). ment of leaf scab (Fig. 11), and several were available for each level of the grower is als. season fungicide schedule and to consider sanitation during the dormant season if the scab risk is very high. In a low-risk or, tactics can be employed that reduce cide costs, and use fungicides more compatible with beneficials and fungicideresistance strategies.

A sanitation action threshold identified autumn at scabbed leaves assessed in the ascospore dose to that of a low-scabrisk orchard, and an orchard within that range of scabbed leaves was designated scab-risk. The sanitation zone applying urea or shredding the leaf litter (Fig. 12), that lowered the ascosporic inoculum by at least $50 \%$ (79). An orchard 11 is based on two sanitation practices, 
with 80 scabbed leaves in the autumn assessment, for example, would be considered to have 40 scabbed leaves if the leaf litter were shredded, and 40 scabbed leaves is within the range of a low-scab-risk orchard (Fig. 11).

The significance of the sanitation action threshold is that sanitation is coupled to tactics (e.g., urea treatment-leaf-shredding, leaf removal) that reduce the fungicide dose and lower management costs. The tactic(s) a grower selects and the timing of each fungicide application will depend on factors such as sanitation equipment available, ground-cover characteristics, cultivar susceptibility to scab, frequency and amount of rain, fungicide needs for other diseases, and the scheduling of insecticides. In addition to its use with the sanitation action threshold, sanitation enhances the effectiveness of all management practices (Fig. 13). By reducing the ascospore dose $50 \%$ or more with sanitation in a moderate- or low-scab-risk orchard, for example, (i) a mediocre fungicide might provide acceptable control and perhaps replace a more efficacious but less environmentally friendly or more expensive fungicide, (ii) it would be less likely that a more fungicide-tolerant strain of the fungus would build up, (iii) it would be less likely that a strain of the fungus capable of infecting a scab-resistant cultivar would become established, and (iv) there would be less scab in a mixed-cultivar planting.

\section{Scab Management in the Twenty-first Century}

Research over the last two decades has had two important effects on scab management programs in the northeastern United States: a shift in emphasis from a regional to an individual-orchard management program and from a predominantly defensive to a more balanced offensive- defensive program. The shift to an individual-orchard management program is due to the development of a procedure to predict an orchard's level of scab risk (ascospore dose) and an action threshold for fungicide decision-making based on that prediction. The individual-orchard approach is significant in that it recognizes that the ascospore dose, and thus the scab risk (potential for scab buildup), can differ greatly from one orchard to another in a region. In nine commercial orchards in New Hampshire in 1983, for example, the predicted potential ascospore dose ranged from 25 to $1,505,027$ ascospores per square meter of orchard floor (28). Before the development of this program, the risk of scab in all these orchards would have been assumed to be great, and consequently all would be given full-season protection with fungicide. However, modern methods would predict that five of the nine orchards were low risk.

The shift to offensive practices is due to the development of a sanitation action threshold in which sanitation practices are employed to economic advantage. Sanitation practices under investigation include the use of biological agents that attack the pathogen or decompose the leaf litter and equipment to shred or remove the leaf litter (W. E. MacHardy, personal communication). Planting cultivars with more durable resistance to scab, planting mixed-cultivar orchards, and increased emphasis on biologically and culturally based practices aimed at reducing initial inoculum (coupled with action thresholds and strategies to reduce the seasonal fungicide dose) are the most likely approaches for substantial further reductions in fungicide.

Biological agents may have a greater role in sanitation in the twenty-first century. A postharvest application of $\mathrm{Mi}$ crosphaeropsis sp., for example, reduced

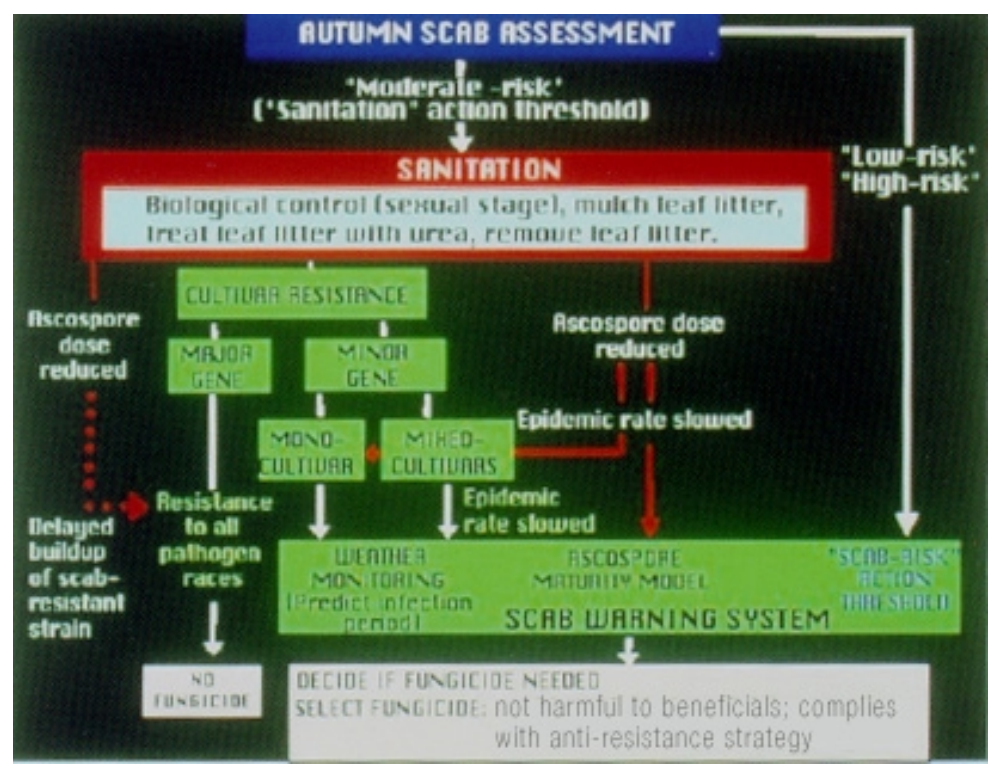

Fig. 13. Schematic representation of scab management practices.

the total amount of airborne ascospores trapped by 70.7 and $79.8 \%$ in 1997 and 1998, respectively, compared with untreated plots (18), and this is within the range reported for urea and leaf shredding (79). Much more needs to be learned about the leaf environment and epiphytic microbial communities, however, before significant advances can be expected in biological control of foliar pathogens. Timing the application of an antagonist is critical. If it is applied to the trees too early, some leaves may be missed or the antagonist may not survive at a suitable density or have colonized the leaf sufficiently by the time of leaf abscission; if applied after leaf fall, some leaves will be inaccessible and the biotic agent may not have time to become established and interfere with the development of $V$. inaequalis during the critical few weeks after leaf fall when mating occurs. There are also complex cultural, technological, and application problems to be solved. Andrews (3) estimated, for example, that the biomass of Athelia bombacina needed per hectare of apple orchard to treat leaf litter in the autumn for scab control is something on the order of $1,000 \mathrm{~kg}$ (wet weight). Is the market potential sufficient to justify the investment needed to produce, store, and apply the amounts of this antagonist needed to control scab?

Soil fauna, mainly earthworms, have been shown to reduce the ascosporic inoculum substantially through chewing and burying leaves (66). Practices to maintain the earthworm population at or above a designated effective density must include consideration of several factors such as food availability and palatability (of apple leaves) and, most importantly, the selection of pesticides (e.g., avoid benzimidazole fungicides) and other chemicals that are not harmful to earthworms. Without appropriate chemical management, earthworms are not likely to be factored into a strategy to integrate practices for reducing fungicide dose in the management of apple scab.

\section{Research Requirements}

Nelson (59) noted that "Breeding for race-specific disease resistance and the resulting population shifts of plant pathogens has, among other things, taken the host and parasite out of the genetic equilibrium that apparently existed prior to human intervention." To date, this has happened with all major resistance genes (the ephemeral R-genes) and for Vf bred into the domestic apple. Is it possible to develop a cultivar with durable resistance to scab?

The first strategy to achieve durable resistance is to pyramid in a single cultivar several exotic resistance genes, e.g., resistance genes that are still fully effective in their region because no coevolution with the local $V$. inaequalis population has oc- 
curred (i.e., the hypersensitive response has remained effective) and strict quarantine has prevented the import of compatible genotypes. The rationale is that the pathogen would have to mutate several avirulence genes to virulence genes before it could successfully infect a cultivar with such pyramided genes.

The second strategy is to assemble several quantitative, minor-effect resistance loci. The rational would be: they are truly horizontal resistances or, if vertical, selection pressure of each single locus was, and is, too low to select the corresponding virulence.

Combining the two strategies would probably lead to the desired level of durable resistance. To implement such strategies, however, there must be easily selectable markers of major genes and of resistance quantitative trait loci (QTLs). Some are already available, and worldwide there are several large projects (e.g., the EU-community D.A.R.E. project) that involve marker-assisted resistance breeding. Further assistance could come from biotechnology once resistance genes are identified. These genes could be cloned and replace, by positional cloning, alleles of ineffective genes, envisaging a gene therapy of cultivars defective in resistance.

There is also the need to increase the efficiency of sanitation. The most promising procedure is leaf removal. It has been demonstrated that a sweep and vacuum technique can remove over $90 \%$ of the leaf litter, thus reducing the ascosporic inoculum by more than $90 \%$ (W. E. MacHardy, unpublished data), but further research is needed to determine its full potential for reducing the need for fungicide.

\section{Concluding Remarks}

$V$. inaequalis is not life threatening to apple, but it is a continual threat to the apple industry. The pathogen is not going to go away, nor can we expect that the pathogen and host will coevolve to a level where there is infection of fruit without production of a sporulating lesion that lowers the value of fruit. We do not envision scab being managed without fungicide in this century unless there are breakthroughs in biotechnology that result in cultivars with durable resistance. Nor do we envision new horticultural (cultural) practices that will render the host less susceptible to scab. We do expect, however, that by (i) strengthening the host's natural (horizontal) resistance, (ii) increasing host genetic diversity in orchards through cultivar selection based on our understanding of pathogen race evolution in orchards, and (iii) exploiting vulnerable links in the pathogen's life cycle through placing greater emphasis on sanitation practices that reduce the inoculum dose available to cause infection, a truly integrated program will evolve to manage scab that is acceptable to consumers and to growers and is fully compliant with integrated crop production standards.

\section{Acknowledgments}

Appreciation is expressed to Robert Blanchard and Cheryl Smith for helpful comments on the manuscript. Scientific contribution 2093 from the New Hampshire Agricultural Experiment Station.

\section{Literature Cited}

1. Aderhold, R. 1896. Die Fusicladien unserer Obstbäume. I. Teil. Landwirtsch. Jahrb. Schweiz. 25:875-914.

2. Aderhold, R. 1899. Auf welche Weise können wir dem immer weiteren Umsichgreifen des Fusicladiums in unseren Apfelkulturen begegnen und welche Sorten haben sich bisher dem Pilz gegenüber am widerstandsfähigsten gezeigt. Pomol. Monatsh. XLV:266-272.

3. Andrews, J. H. 1992. Biological control in the phyllosphere. Annu. Rev. Phytopathol. 30:603-635.
4. Aylor, D. E. 1998. The aerobiology of apple scab. Plant Dis. 82:838-849.

5. Aylor, D. E., and Anagnostakis, S. L. 1991. Active discharge distance of ascospores of Venturia inaequalis. Phytopathology 81:548551.

6. Bagga, H. S., and Boone, D. M. 1968. Genes in Venturia inaequalis controlling pathogenicity to crabapples. Phytopathology 58:11761182

7. Bagga, H. S., and Boone, D. M. 1968. Inheritance of resistance to Venturia inaequalis in crabapples. Phytopathology 58:1183-1187.

8. Beach, S. A., Booth, N. O., and Taylor, O. M. 1905. Report of the NYAES for 1903. Vol. 1, The Apples of New York. J. B. Lyon Company, Printers.

9. Bénaouf, G., and Parisi, L. 1997. Pathogenicity of Venturia inaequalis strains from Malus floribunda 821: Comparison with race 6 on apple clones. Pages 8-11 in: Integrated Control of Pome Fruit Diseases. Proc of 4th Workshop. A. M. Berrie et al., eds. IOBC/ WPRS Bull. Vol. 20(9):8-11.

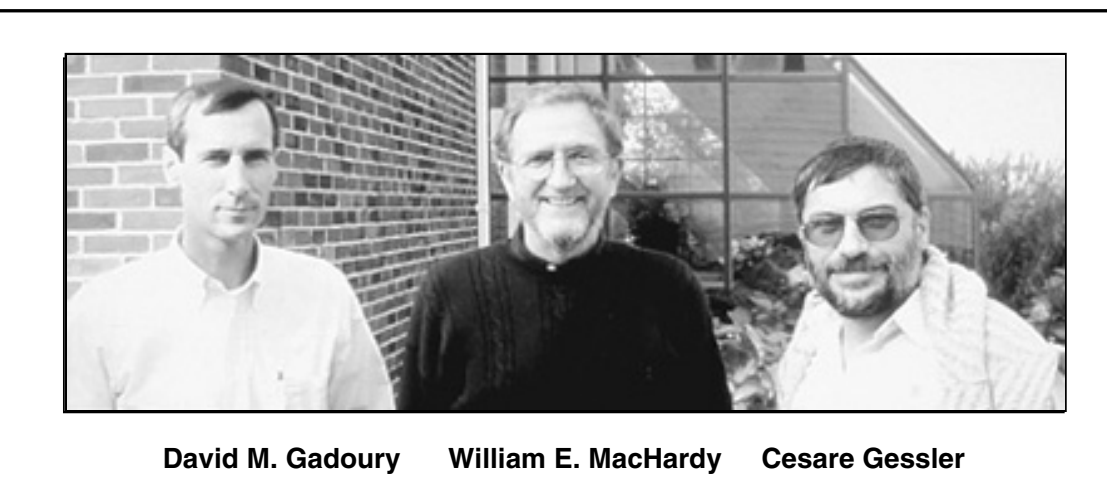

Dr. MacHardy is professor of plant pathology at the University of New Hampshire. He received his B.S. in Science (1958) and M.Ed. in science education (1965) at the University of Maine, his M.S. in biology at the University of Nebraska at Omaha (1966), and his Ph.D. in biological sciences at the University of Rhode Island (1970). He has had responsibilities in teaching, research, and extension at the University of New Hampshire since 1972. Since 1978, his research has focused on the biology, epidemiology, and management of apple scab. He has served on numerous regional IPM committees, was president of the NE Division of APS in 1987, and in 1996 received the division's Award of Merit. He currently has collaborations on apple scab management with researchers in New Zealand, Australia, and several European countries.

Dr. Gadoury is a senior research associate at Cornell University's experiment station in Geneva, New York. He received his B.S. (1978) degree from the University of Rhode Island, Kingston; and his M.S. (1981) and Ph.D. (1984) degrees from the University of New Hampshire, Durham. His research has focused upon areas of pathogen biology, ecology, and epidemiology that are poorly understood, and which severely constrain our ability to manage diseases of grapevine and apple. Examples include investigations of the role of absolute inoculum potential in development of apple scab epidemics, the role of cleistothecia in the epidemiology of grape powdery mildew, and the impact of ontogenic resistance in management of grape powdery mildew, details of which may be found on the Cornell University Website.

Dr. Gessler is a senior research scientist and lecturer in plant pathology at the Swiss Federal Institute of Technology in Zürich (ETH). He received his diploma in agricultural engineering and $\mathrm{Ph}$.D. degree in plant pathology at this Institution in 1977. He was a visiting scientist from 1979 to 1980 in Professor J. Kuç's lab at the University of Kentucky. In 1980, he joined plant pathology again at the ETH where he has remained since. His main research interests are apple scab and powdery mildew and grape downy mildew. His research team spans from molecular genetics of scab resistance genes to epidemiology and forecasting of grape downy mildew. His teaching duties cover classical plant pathology, diagnoses, and tropical plant pathology. Currently, he serves as treasurer of the IOBC/west paleartic regional section. 
10. Berton, O., Gadoury, D. M., Seem, R. C., and Wilcox, W. F. 1999. Ontogenic resistance to apple scab, post-infection use of fenarimol, and the distribution of symptom expression. (Abstr.) Phytopathology 89:S6

11. Blaise, P., and Gessler, C. 1994. Cultivar mixtures in apple orchards as a means to control apple scab. Pages 105-112 in: Integrated Control of Pome Fruit Diseases. Denis J. Butt, ed. Norw. J. Agric. Sci. Suppl. No. 17.

12. Boone, D. M. 1971. Genetics of Venturia inaequalis. Annu. Rev. Phytopathol. 9:297318 .

13. Boone, D. M., and Keitt, G. W. 1957. Venturia inaequalis (Cke.) Wint. XII. Genes controlling pathogenicity of wild-type lines. Phytopathology 47:403-409.

14. Brook, P. J. 1969. Effects of light, temperature, and moisture on release of ascospores by Venturia inaequalis (Cke.) Wint. N.Z. J. Agric. Res. 12:214-227.

15. Brook, P. J. 1969. Stimulation of ascospore release in Venturia inaequalis by far red light. Nature 222:390-392.

16. Brown, A. G. 1975. Apples. Pages 3-37 in: Advances in Fruit Breeding. J. Janick and J. N. Moore, eds. Purdue University Press, West Lafayette, IN.

17. Butler, O. 1925. Control of apple scab. N.H. Agric. Exp. Stn. Circ. 25

18. Carisse, O., Philion, V., Rolland, D., and Bernier, J. 2000. Effect of fall application of fungal antagonists on spring ascospore production of the apple scab pathogen, Venturia inaequalis. Phytopathology 90:31-37.

19. Falk, S. P., Gadoury, D. M., and Seem, R. C. 1995. Analysis of risk of primary apple scab infection. (Abstr.) Phytopathology 85:1556.

20. Falk, S. P., Gadoury, D. M., and Seem, R. C. 1996. Impact of fenarimol on symptom expression and survival of stromata of Venturia inaequalis. (Abstr.) Phytopathology 86:S121.

21. Falk, S. P., Gadoury, D. M., and Seem, R. C. 1996. Impact of ontogenic resistance and fenarimol on seasonal development of scab on apple foliage. (Abstr.) Phytopathology 86:S85-86.

22. Fries, E. 1819. Spilocaea pomi, Fr. Nov. Fl. Suec. 5:79

23. Fulleman, M., Fulleman, V., and Bänninger, A. 1997. Eine Art Kulturgeschichte des Apfels, Bentely. Verlag Bern 197: pp. ISBN 3-7165-1070-X.

24. Gadoury, D. M., and MacHardy, W. E. 1982. A model to estimate the maturity of ascospores of Venturia inaequalis. Phytopathology 72:901-904.

25. Gadoury, D. M., and MacHardy, W. E. 1984. Integration of fungicide and insecticide applications in low inoculum orchards, 1983. Fungic. Nematicide Tests 39:10.

26. Gadoury, D. M., and MacHardy, W. E. 1985. Epidemiological analysis and the integration of fungicide and insecticide applications in low inoculum orchards, 1983. Fungic. Nematicide Tests 40:6-7.

27. Gadoury, D. M., and MacHardy, W. E. 1985. Negative geotropism in Venturia inaequalis. Phytopathology 75:856-859.

28. Gadoury, D. M., and MacHardy, W. E. 1986. Forecasting ascospore dose of Venturia inaequalis in commercial apple orchards. Phytopathology 76:112-118

29. Gadoury, D. M., MacHardy, W. E., and Hu, C. 1984. Effects of temperature during ascus formation and frequency of ascospore discharge on pseudothecial development of Venturia inaequalis. Plant Dis. 68:223-225.

30. Gadoury, D. M., MacHardy, W. E., and Rosenberger, D. A. 1989. Integration of pesticide application schedules for disease and insect control in apple orchards of the northeastern United States. Plant Dis. 73:98-105.
31. Gadoury, D. M., and Pearson, R. C. 1991. Heterothallism and pathogenic specialization in Uncinula necator. Phytopathology 81:1287-1293.

32. Gadoury, D. M., Seem, R. C., Rosenberger, D. A., Wilcox, W. F., MacHardy, W. E., and Berkette, L. P. 1992. Disparity between morphological maturity of ascospores and physiological maturity of asci in Venturia inaequalis. Plant Dis. 76:717-720.

33. Gadoury, D. M., Seem, R. C., and Stensvand, A. 1994. Ascospore discharge in Venturia inaequalis. Norw. J. Agric. Sci. Suppl. 17:205219.

34. Gadoury, D. M., Stensvand, A., and Seem, R. C. 1998. Influence of light, relative humidity, and maturity of populations on discharge of ascospores of Venturia inaequalis. Phytopathology 88:902-909.

35. Gessler, C. 1989. Genetics of the interaction Venturia inaequalis - Malus: The conflict between theory and reality. Pages 168-190 in: Integrated Control of Pome Fruit Diseases, IOBC Bull. Vol. II. C. Gessler, D. J. Butt, and B. Koller, eds. WPRS-Bull. XII/6.

36. Hernàndez Castillo, F. D., Parisi, L., and Lespinasse, Y. 1994. Heredabilidad del factor de avirulencia de una cepa de Venturia inaequalis (Cke.) Wint. sobre el cultivar manzano (Malus $\times$ domestica Borkh.) Golden Delicious. Rev. Mex. Fitopatol. 12:31-34

37. Hirst, J. M., and Stedman, O. J. 1962. The epidemiology of apple scab (Venturia inaequalis (Cke.) Wint.) II. Observations on the liberation of ascospores. Ann. Appl. Biol. 50:525-550.

38. Johnstone, K. H. 1931. Observations on the varietal resistance of the apple to scab (Venturia inequalis, Aderh.) with special reference to its physiological aspects. J. Pomol. 9:3052; 195-221.

39. Julien, J. B., and Spangelo, L. P. S. 1957. Physiological races of Venturia inaequalis. Can. J. Plant Sci. 37:102-107.

40. Keitt, G. W. 1952. Inheritance of pathogenicity in Venturia inaequalis (Cke.) Wint. Am. Naturalist 86:373-390.

41. Keitt, G. W., and Langford, M. H. 1941. A preliminary report on genetic studies on pathogenicity and the nature of saltation in Venturia inaequalis. Phytopathology 31:1142.

42. Keitt, G. W., Langford, M. H., and Shay, J. R. 1943. Venturia inaequalis (Cke.) Wint. II. Genetic studies on pathogenicity and certain mutant characters. Am. J. Bot. 30:491-500.

43. Keitt, G. W., Leben, C., and Shay, J. R. 1946. Inheritance of pathogenicity and sex reaction in Venturia inaequalis. (Abstr.) Phytopathology 36:403.

44. Keitt, G. W., Leben, C., and Shay, J. R. 1948. Venturia inaequalis (Cke.) Wint. IV. Further studies on the inheritance of pathogenicity. Am. J. Bot. 35:334-336.

45. Keitt, G. W., and Palmiter, D. H. 1937. Potentialities of eradicant fungicides for combating apple scab and some other plant diseases. J. Agric. Res. 55:397-436.

46. Keitt, G. W., and Palmiter, D. H. 1938. Hetero-thallism and variability in Venturia inaequalis. Am. J. Bot. 25:338-345.

47. Knight, T. A. 1806. Observations on the means of producing new and early fruits. Trans. Hortic. Soc. London 1:30-37.

48. Koch, M., Kellerhals, M., and Gessler, C. 2000. Virulence pattern of Venturia inaequalis field isolates and corresponding differential resistance in Malus $\times$ domestica. J. Phytopathol. 148:357-364.

49. Leppik, E. E. 1970. Gene centers of plants as sources of disease resistance. Annu. Rev. Phytopathol. 8:323-344.

50. MacHardy, W. E. 1994. A "PAD" action threshold: The key to integrating practices for managing apple scab. Pages 75-82 in: Integrated Control of Pome Fruit Diseases. Denis J. Butt, ed. Norw. J. Agric. Sci. Suppl. 17.

51. MacHardy, W. E. 1996. Apple Scab: Biology, Epidemiology, and Management. American Phytopathological Society, St. Paul, MN.

52. MacHardy, W. E. 2000. Action thresholds for managing apple scab with fungicides and sanitation. IOBC/WPRS Bull. 23(7):123-131.

53. MacHardy, W. E. 2000. Current status of IPM in apple orchards, Crop Prot. 19:801-806.

54. MacHardy, W. E., and Gadoury, D. M. 1986. Patterns of ascospore discharge by Venturia inaequalis. Phytopathology 76:985-990.

55. MacHardy, W. E., Gadoury, D. M., and Rosenberger, D. A. 1993. Delaying the onset of fungicide programs for control of apple scab in orchards with low potential ascospore dose of Venturia inaequalis. Plant Dis. 77:372-375.

56. MacHardy, W. E., and Sutton, D. K. 1995. Integrating sanitation practices with fungicide applications to reduce fungicide dose in controlling apple scab. Abstr. 3011/0523 in: Proc. XIII Int. Plant Prot. Congr. The Hague.

57. Moore, M. H. 1958. The release of ascospores of apple scab by dew. Plant Pathol. 7:4-5.

58. Müller, W. C., and Darbellay, C. 1997. Entwicklung und Bedeutung des Obstbaus. Pages 7-26 in: Obstbau: M. Kellerhals, W. C. Müller, L. Bertschinger, C. Darbellay, and C. W. Pfammater, eds. Landwirtsch. Lehrmittelzentrale, Zollikofen, Switzerland.

59. Nelson, R. R. 1979. The evolution of parasitic fitness. Pages 23-46 in: Plant Disease - an Advanced Treatise, Vol. IV. J. G. Horsfall and E. B. Cowling, eds. Academic Press, New York

60. Oberhofer, H. 1985. Der Apfelschorf. Lebensweise und Bekämpfung. Obst—Weinbau 21 (Suppl. II)

61. Palmiter, D. H. 1932. Variability of Venturia inaequalis in cultural characters and host relations. (Abstr.) Phytopathology 22:21.

62. Palmiter, D. H. 1934. Variability in monoconidial cultures of Venturia inaequalis. Phytopathology 24:22-47.

63. Palmiter, D. H. 1940. Eradicant treatments as an aid in the control of apple scab. (Abstr.) Phytopathology 30:18.

64. Palmiter, D. H. 1946. Ground treatments as an aid in apple scab control. N.Y. Agric. Exp. Stn. Bull. 714.

65. Parisi, L., Lespinasse, Y., Guillaumes, J., and Kruger, J. 1993. A new race of Venturia inaequalis virulent to apples with resistance due to the Vf gene. Phytopathology 83:533-537.

66. Raw, F. 1962. Studies of earthworm populations in orchards. I. Leaf burial in apple orchards. Ann. Appl. Biol. 50:389-404.

67. Rudloff, C. F., and Schmidt, M. 1934. Venturia inaequalis (Cooke) Aderh. II. Zur Züchtung schorfwiderstandsfähiger Apfelsorten Der Züchter 6:288-294.

68. Rudloff, C. F., and Schmidt, M. 1935. Der Erreger des Apfelschorfes Venturia inaequalis (Cooke) Aderh. Grundlagen und Möglichkeiten für seine Bekämpfung auf züchterischen Wage II. Der Züchter 7:65-74.

69. Schmidt, M. 1935. Venturia inaequalis (Cooke) Aderh. IV. Weitere Beiträge zur Rassenfrage beim Erreger des Apfelschorfes. Gartenbauwissenschaft 9:364-389.

70. Schmidt, M. 1936. Venturia inaequalis (Cooke) Aderhold. V. Weitere Untersuchungen über die auf verschiedenen Bäumen lebenden Populationen des Apfelschorfpilzes. Gartenbauwissenschaft 10:422-427.

71. Schmidt, M. 1936b. Venturia inaequalis (Cooke) Aderhold. VI. Zur Frage nach dem Vorkommen physiologisch specialisierter Rassen beim Erreger des Apfelschorfes. Erste Mitteilung. Gartenbauwissenschaft 10:478 
499.

72. Schmidt, M. 1940. Venturia inaequalis (Cooke) Aderhold. X. Zur Vererbung der morphologischen Merkmale auf künstlichem Substrat und der Agressivität gegenüber bestimmten Wirten bei Einsporenherkünften des Apfelschofpilzes. Gartenbauwissenschaft 15:118-130.

73. Shay, J. R., Williams, E. B., and Janick, J. 1962. Disease resistance in apple and pear. Proc. Am. Soc. Hortic. Sci. 80:97-104.

74. Sierotzki, H., Eggenschwiler, M., Boillat, O., McDermott, J. M., and Gessler, C. 1994. Detection of variation in virulence toward susceptible apple cultivars in natural populations of Venturia inaequalis. Phytopathology 84:1005-1009.

75. Sierotzki, H., and Gessler, C. 1998. Inheritance of virulence in Venturia inaequalis toward Malus $\times$ domestica cultivars. J. Phytopathol. 146:515-520.

76. Smereka, K. J., MacHardy, W. E., and Kausch, A. P. 1987. Cellular differentiation in
Venturia inaequalis ascospores during germination and penetration of apple leaves. Can. J. Bot. 65:2549-2561.

77. Stensvand, A., Amundsen, T., Semb, L., Gadoury, D. M., and Seem, R. C. 1998. Discharge and dissemination of ascospores by Venturia inaequalis during dew. Plant Dis. 82:761-764.

78. Stensvand, A., Gadoury, D. M., Amundsen, T., Semb, L., and Seem, R. C. 1997. Ascospore release and infection of apple leaves by conidia and ascospores of Venturia inaequalis at low temperatures. Phytopathology 87:10461053.

79. Sutton, D. K., MacHardy, W. E., and Lord, W. G. 2000. Effects of shredding or treating apple leaf litter with urea on ascospore dose of Venturia inaequalis and disease buildup. Plant Dis. 84:1319-1326.

80. Turner, M. L., MacHardy, W. E., and Gadoury, D. M. 1986. Germination and appressorium formation by Venturia inaequalis during infection of apple seedling leaves. Plant Dis.
70:658-661.

81. Valsangiacomo, C., and Gessler, C. 1988 Role of the cuticular membrane in ontogenic and Vf-resistance of apple leaves against Venturia inaequalis. Phytopathology 78:10661069.

82. Wallace, E. 1913. Scab disease of apples. N.Y. Agric. Exp. Stn. Bull. 335.

83. Wiesmann, R. 1931. Untersuchungen über Apfel- und Birnenschorfpilz Fusicladium dendriticum (Wallr.) Fckl. und Fusicladium pirinum (Lib.) Fckl. sowie die Schorfanfälligkeit einzelner Apfel- und Birnensorten Landwirtsch. Jahrb. Schweiz. 45:109-156.

84. Wiesmann, R. 1932. Untersuchungen über die Überwinterung des Apfelschorfpilzes Fusicladium dentriticum (Wallr) Fckl. im toten Blatt sowie die Ausbreitung der Sommersporen (Konidien) des Apfelschorfpilzes. Landwirtsch. Jahrb. Schweiz. 36:620-679.

85. Williams, E. B., and Kuc, J. 1969. Resistance in Malus to Venturia inaequalis. Annu. Rev. Phytopathol. 7:223-246. 